\title{
Model simulations of fuel sulfur conversion efficiencies in an aircraft engine: Dependence on reaction rate constants and initial species mixing ratios
}

\author{
Hans Georg Tremmel ${ }^{\mathrm{a}, *}$, Ulrich Schumann ${ }^{\mathrm{a}}$ \\ ${ }^{a}$ Deutsches Zentrum für Luft- und Raumfahrt (DLR), Institut für Physik der Atmosphäre, Oberpfaffenhofen, \\ Postfach 1116, 82230 Wessling, Germany
}

Received 12 May 1999; accepted 2 September 1999

\begin{abstract}
The fuel sulfur conversion efficiency $\varepsilon$ behind the combustor of a JT9D-7A aircraft engine in flight has been simulated using an extended exhaust plume chemistry model. The model simulations start in the hightemperature intra-engine regime behind the combustor. The simulations show that the sulfur conversion efficiency is sensitively dependent on model assumptions like reaction rate constants and initial mixing ratios. Sensitivity studies to demonstrate the effect of the uncertainties and variabilities of these parameters on $\varepsilon$ are presented. Among the rate constants $k$, the uncertainty of the reaction rate constant for $\mathrm{SO}_{2}+\mathrm{OH}+\mathrm{M} \rightarrow$ $\mathrm{HSO}_{3}+\mathrm{M}$ has the greatest effect on $\varepsilon$ : The uncertainty of $k\left(\mathrm{SO}_{2}+\mathrm{OH}\right)$ results in an uncertainty range of $1.1 \%<\varepsilon<6.2 \%$ for our simulation scenario, with a most probable value around $3.8 \%$. The effect of the reaction $\mathrm{SO}_{2}+\mathrm{O}+\mathrm{M} \rightarrow \mathrm{SO}_{3}+\mathrm{M}$ on $\varepsilon$ is very small if the initial mixing ratio of $\mathrm{O}$ is smaller than that of $\mathrm{OH}$. Among the initial mixing ratios, the variation of the initial $\mathrm{OH}$ mixing ratio $\mathrm{OH}_{0}$ has the greatest effect on $\varepsilon$. For our simulation scenario, the uncertainty range of $5.7 \mathrm{ppmv}<\mathrm{OH}_{0}<14.7 \mathrm{ppmv}$ (inferred from measurements) leads to an uncertainty range of $2.7 \%<\varepsilon<5.0 \%$. ( 1999 Éditions scientifiques et médicales Elsevier SAS

fuel sulfur conversion efficiency / aircraft engine / uncertainty / sensitivity study

Zusammenfassung

Modellsimulationen der Schwefel-Konversionseffizienz in einem Flugzeugtriebwerk: Abhängigkeit von Geschwindigkeitskonstanten und Anfangs-Mischungsverhältnissen. Die Treibstoffschwefel-Konversionseffizienz $\varepsilon$ hinter der Brennkammer eines JT9D-7A-Triebwerkes unter Flugbedingungen wurde mit einem detaillierten Abgasfahnen-Chemiemodell simuliert. Als Referenzwert wurde eine Schwefelumwandlung von $\varepsilon=3.8 \%$ gefunden. Die berechnete Schwefelumwandlung hängt dabei ganz entscheidend von den Modellannahmen wie z.B. den Geschwindigkeitskonstanten und den Anfangskonzentrationen ab. Es werden Sensitivitätsstudien präsentiert, die den Einfluß dieser Parameter auf $\varepsilon$ verdeutlichen sollen. Unter den Geschwindigkeitskonstanten $k$ hat $k\left(\mathrm{SO}_{2}+\mathrm{OH}\right)$ den größten Einfluß auf $\varepsilon$ : ihr Fehlerbereich führt zu einer Schwankungsbreite von $\varepsilon$ zwischen 1.1 und 6.2\% für unser Szenario. Der Effekt der Reaktion $\mathrm{SO}_{2}+\mathrm{O}$ ist dagegen eher klein, wenn das Mischungsverhältnis von $\mathrm{O}$ kleiner als das von $\mathrm{OH}$ ist. Unter den AnfangsMischungsverhältnissen hat die Variation des Mischungsverhältnisses von $\mathrm{OH}$ den größten Einfluß auf $\varepsilon$. Für unser Simulations-Szenario führt der Fehler bei der Bestimmung des anfänglichen $\mathrm{OH}-$ Wertes $(\mathrm{OH}$ liegt nach einer Abschätzung aus Messungen für dieses Szenario zwischen 5.7 und 14.7 ppmv) zu einem Bereich von $2.7 \%<\varepsilon<5.0 \%$. ( $) 1999$ Éditions scientifiques et médicales Elsevier SAS
\end{abstract}

*Correspondence and reprints 
Schwefel-Konversionseffizienz / Flugzeugtriebwerk / Treibstoff / Sensitivitätsstudie / AbgasfahnenChemiemodell

\section{Introduction}

In aircraft engines, the combustion of fossil fuels containing sulfur primarily leads to the formation and emission of sulfur dioxide $\left(\mathrm{SO}_{2}\right)$. In the exhaust plume behind the combustor, a small fraction of $\mathrm{SO}_{2}$ subsequently oxidizes to sulfur trioxide $\left(\mathrm{SO}_{3}\right)$ and sulfuric acid $\left(\mathrm{H}_{2} \mathrm{SO}_{4}\right)$, which play an important role as sulfate aerosol precursors [19]. The key oxidation reactions are:

$$
\begin{gathered}
\mathrm{SO}_{2}+\mathrm{O}+\mathrm{M} \rightarrow \mathrm{SO}_{3}+\mathrm{M} \\
\mathrm{SO}_{2}+\mathrm{OH}+\mathrm{M} \rightarrow \mathrm{HSO}_{3}+\mathrm{M} \\
\mathrm{HSO}_{3}+\mathrm{O}_{2} \rightarrow \mathrm{SO}_{3}+\mathrm{HO}_{2} \\
\mathrm{SO}_{3}+\mathrm{H}_{2} \mathrm{O}+\mathrm{M} \rightarrow \mathrm{H}_{2} \mathrm{SO}_{4}+\mathrm{M}
\end{gathered}
$$

The efficiency $\varepsilon$ of fuel-sulfur conversion to $\mathrm{SO}_{3}$ and $\mathrm{H}_{2} \mathrm{SO}_{4}$ in terms of mixing ratios is defined as follows:

$$
\varepsilon=\left(\left[\mathrm{SO}_{3}\right]+\left[\mathrm{H}_{2} \mathrm{SO}_{4}\right]\right) /\left[\mathrm{SO}_{x}\right]
$$

where $\mathrm{SO}_{x}$ denotes the sum of all sulfur compounds $\left(\mathrm{SO}_{2}+\mathrm{SO}_{3}+\mathrm{H}_{2} \mathrm{SO}_{4}+\cdots\right)$.

The magnitude of this sulfur conversion efficiency has been the subject of several studies. Directly measured sulfuric acid at the ground-level yielded $\varepsilon>0.4 \%$ [20]. Arnold et al. measured $\mathrm{H}_{2} \mathrm{SO}_{4}$ and $\mathrm{SO}_{3}$ in the exhaust of the research aircraft ATTAS (Advanced Technology Testing Aircraft System) at the ground, and found a conversion ratio of about $1.2 \%$ [1]. Recently, Curtius et al. directly detected for the first time sulfuric acid in the exhaust plume of a jet aircraft (ATTAS) in flight, indicating a lower limit for $\varepsilon$ of $0.34 \%$ [15]. Measurements of different test gas turbines burning diesel fuel yielded an oxidation to $\mathrm{SO}_{3}$ of between 2 and 22\% [25]. As indirectly inferred from in-flight measurements of volatile particles behind a Concorde supersonic aircraft, Fahey et al. estimated a lower limit for $\varepsilon$ of about $12-45 \%$ [18], and Miake-Lye et al. reported estimated conversion efficiencies behind a B757 in flight of about $6 \%$ and 31\% [35]. Sulfur conversion efficiencies inferred from indirectly measured $\mathrm{EI}(\mathrm{OH})$ amount to about $1-2 \%$ behind a Concorde [22] and $0.4-0.6 \%$ behind a B747 [40]. In general, several modelling studies starting behind the engine exit with various initial and boundary conditions have revealed that about $0.5-2 \%$ of the fuel sulfur is oxidized to sulfuric acid in the gas phase (e.g.: [6,28]). Modelling studies considering the oxidation within the aircraft engine (combustor and turbine flow section) show that sulfur conversion efficiencies of up to $10 \%$ can be ex- pected $[7,26,33]$. In theoretical studies, Kärcher and Fahey [29], and Yu and Turco [44] inferred $\varepsilon=25-60 \%$, and $\varepsilon>20-30 \%$, respectively, from the Concorde measurements. Some of the modelling studies tested the sensitivity of $\varepsilon$ on selected parameters like fuel sulfur content [7], initial $\mathrm{OH}$ mixing ratio and $\mathrm{EI}\left(\mathrm{NO}_{x}\right)$ [28], or several engine parameters [33]. Still, a comprehensive parameter study discussing in detail the sensitivity of $\varepsilon$ on a large set of parameters is not available.

In this paper, we want to show that simulated fuel sulfur conversion efficiencies are crucially dependent on model assumptions like reaction rate constants and initial mixing ratios. After a description of our exhaust plume chemistry model (next section), sensitivity studies will be presented demonstrating the effect of the uncertainties and variabilities of these parameters on $\varepsilon$.

\section{Chemistry model for the postcombustor exhaust plume}

To investigate the gas phase oxidation of sulfur dioxide to sulfur trioxide and sulfuric acid, we have used a model that is based on the aircraft exhaust plume model described in [40]. To better account for the intra-engine high-temperature regime between the combustor exit and the nozzle exit, this model has been extended by incorporating a more detailed inorganic reaction scheme. The corresponding reaction cycles for the chemistry of $\mathrm{O}_{x}$, $\mathrm{HO}_{x}, \mathrm{NO}_{x}, \mathrm{CO}$, and $\mathrm{SO}_{x}$ are listed in table I. For each equation, the forward and reverse reaction is considered. The reaction rate constants are extracted from the NIST (National Institute of Standards and Technology) chemical kinetics database [34]. This database comprises a large body of published rate constant data applicable for temperatures up to about $2500 \mathrm{~K}$ (e.g., evaluations by Tsang and Hampson [41], Tsang and Herron [42], and Baulch et al. [5]). As far as available, the rate constants used in the present study are also listed in table I.

The incorporation of these additional inorganic reactions including appropriate rate constants represents the major modification of the chemistry model for aircraft exhaust plumes. The rest of the model including photolytic and organic reactions, as well as time-dependent functions has already been described in detail by Tremmel et al. [40]. Altogether, the complete extended model is applicable for the intra-engine section between the combustor exit and the nozzle exit as well as for the expanding exhaust plume behind the engine exit.

The calculations have been performed for a JT9D7A engine at cruising altitude with initial and bound- 
Table I. Inorganic gas phase chemical reaction mechanism of the postcombustor exhaust plume model (organic reactions, see [40]).

\begin{tabular}{|c|c|c|c|c|c|c|c|}
\hline \multirow[b]{2}{*}{ Reaction } & & \multicolumn{3}{|c|}{$k_{\mathrm{f}}$} & \multicolumn{3}{|c|}{$k_{\mathrm{r}}$} \\
\hline & & $A$ & $n$ & $E_{a} / R$ & $A$ & $n$ & $E_{a} / R$ \\
\hline $\mathrm{O}+\mathrm{O}+\mathrm{M} \leftrightarrow \mathrm{O}_{2}+\mathrm{M}$ & & $5.21 \mathrm{E}-35$ & 0.00 & -900.0 & $3.01 \mathrm{E}-06$ & -1.00 & 59429.0 \\
\hline $\mathrm{O}+\mathrm{O}_{2}+\mathrm{M} \leftrightarrow \mathrm{O}_{3}+\mathrm{M}$ & $\left\{\begin{array}{l}\left(k_{0}\right) \\
\left(k_{\infty}\right)\end{array}\right.$ & $\begin{array}{l}5.75 \mathrm{E}-31 \\
4.20 \mathrm{E}-12\end{array}$ & $\begin{array}{r}-1.31 \\
0.00\end{array}$ & $\begin{array}{r}-152.6 \\
183.0\end{array}$ & $1.16 \mathrm{E}-09$ & 0.00 & 11490.0 \\
\hline $\mathrm{O}+\mathrm{OH} \leftrightarrow \mathrm{H}+\mathrm{O}_{2}$ & & $1.83 \mathrm{E}-11$ & 0.00 & -173.3 & $3.30 \mathrm{E}-10$ & 0.00 & 8460.0 \\
\hline $\mathrm{O}+\mathrm{HO}_{2} \leftrightarrow \mathrm{OH}+\mathrm{O}_{2}$ & & $2.90 \mathrm{E}-11$ & 0.00 & -200.0 & $3.70 \mathrm{E}-11$ & 0.00 & 26500.0 \\
\hline $\mathrm{O}+\mathrm{O}_{3} \leftrightarrow \mathrm{O}_{2}+\mathrm{O}_{2}$ & & $1.21 \mathrm{E}-11$ & 0.00 & 2125.0 & $1.11 \mathrm{E}-11$ & 0.00 & 49919.0 \\
\hline $\mathrm{O}+\mathrm{H}+\mathrm{M} \leftrightarrow \mathrm{OH}+\mathrm{M}$ & & $1.30 \mathrm{E}-29$ & -1.00 & 0.0 & $4.00 \mathrm{E}-09$ & 0.00 & 50000.0 \\
\hline $\mathrm{H}+\mathrm{H}+\mathrm{M} \leftrightarrow \mathrm{H}_{2}+\mathrm{M}$ & & $1.50 \mathrm{E}-29$ & -1.30 & 0.0 & $7.59 \mathrm{E}-05$ & -1.40 & 52530.0 \\
\hline $\mathrm{H}+\mathrm{O}_{2}+\mathrm{M} \leftrightarrow \mathrm{HO}_{2}+\mathrm{M}$ & $\left\{\begin{array}{l}\left(k_{0}\right) \\
\left(k_{\infty}\right)\end{array}\right.$ & $\begin{array}{l}1.05 \mathrm{E}-30 \\
2.71 \mathrm{E}-11\end{array}$ & $\begin{array}{r}-0.70 \\
0.00\end{array}$ & $\begin{array}{r}-144.2 \\
383.0\end{array}$ & $2.00 \mathrm{E}-05$ & -1.18 & 24363.0 \\
\hline $\mathrm{H}+\mathrm{O}_{3} \leftrightarrow \mathrm{OH}+\mathrm{O}_{2}$ & & $2.03 \mathrm{E}-11$ & 0.24 & 333.4 & & & \\
\hline $\mathrm{H}+\mathrm{HO}_{2} \leftrightarrow \mathrm{OH}+\mathrm{OH}$ & & $2.80 \mathrm{E}-10$ & 0.00 & 440.0 & $1.82 \mathrm{E}-40$ & 0.00 & 0.0 \\
\hline $\mathrm{H}+\mathrm{HO}_{2} \leftrightarrow \mathrm{H}_{2} \mathrm{O}+\mathrm{O}$ & & $5.00 \mathrm{E}-11$ & 0.00 & 866.0 & $1.23 \mathrm{E}-53$ & 0.00 & 0.0 \\
\hline $\mathrm{H}+\mathrm{HO}_{2} \leftrightarrow \mathrm{H}_{2}+\mathrm{O}_{2}$ & & $7.10 \mathrm{E}-11$ & 0.00 & 710.0 & $2.40 \mathrm{E}-10$ & 0.00 & 28500.0 \\
\hline $\mathrm{OH}+\mathrm{H} \leftrightarrow \mathrm{H}_{2}+\mathrm{O}$ & & $8.10 \mathrm{E}-21$ & 2.80 & 1950.0 & $8.49 \mathrm{E}-20$ & 2.67 & 3160.0 \\
\hline $\mathrm{OH}+\mathrm{H}+\mathrm{M} \leftrightarrow \mathrm{H}_{2} \mathrm{O}+\mathrm{M}$ & & $6.11 \mathrm{E}-26$ & -2.00 & 0.0 & $5.80 \mathrm{E}-09$ & 0.00 & 52900.0 \\
\hline $\mathrm{OH}+\mathrm{H}_{2} \leftrightarrow \mathrm{H}+\mathrm{H}_{2} \mathrm{O}$ & & $1.14 \mathrm{E}-16$ & 1.64 & 1589.0 & $7.51 \mathrm{E}-16$ & 1.60 & 9720.0 \\
\hline $\mathrm{OH}+\mathrm{O}_{3} \leftrightarrow \mathrm{HO}_{2}+\mathrm{O}_{2}$ & & $1.90 \mathrm{E}-12$ & 0.00 & 1000.0 & $\cdots$ & & \\
\hline $\mathrm{OH}+\mathrm{OH} \leftrightarrow \mathrm{H}_{2}+\mathrm{O}_{2}$ & & & & & $7.43 \mathrm{E}-13$ & 0.00 & 17340.0 \\
\hline $\mathrm{OH}+\mathrm{OH} \leftrightarrow \mathrm{O}+\mathrm{H}_{2} \mathrm{O}$ & & $8.38 \mathrm{E}-17$ & 1.54 & -355.7 & $6.18 \mathrm{E}-11$ & 0.00 & 9021.0 \\
\hline $\mathrm{OH}+\mathrm{OH}+\mathrm{M} \leftrightarrow \mathrm{H}_{2} \mathrm{O}_{2}+\mathrm{M}$ & & $3.57 \mathrm{E}-26$ & -2.00 & 0.0 & $2.14 \mathrm{E}+09$ & -4.86 & 26795.0 \\
\hline $\mathrm{OH}+\mathrm{HO}_{2} \leftrightarrow \mathrm{H}_{2} \mathrm{O}+\mathrm{O}_{2}$ & & $4.80 \mathrm{E}-11$ & 0.00 & -250.0 & $7.70 \mathrm{E}-12$ & 0.00 & 37280.0 \\
\hline $\mathrm{OH}+\mathrm{HO}_{2} \leftrightarrow \mathrm{H}_{2} \mathrm{O}_{2}+\mathrm{O}$ & & & & & $1.60 \mathrm{E}-17$ & 2.00 & 2000.0 \\
\hline $\mathrm{HO}_{2}+\mathrm{O}_{3} \leftrightarrow \mathrm{OH}+\mathrm{O}_{2}+\mathrm{O}_{2}$ & & $1.40 \mathrm{E}-14$ & 0.00 & 600.0 & & & \\
\hline $\mathrm{HO}_{2}+\mathrm{H}_{2} \leftrightarrow \mathrm{H}_{2} \mathrm{O}_{2}+\mathrm{H}$ & & $5.00 \mathrm{E}-11$ & 0.00 & 13100.0 & $8.00 \mathrm{E}-11$ & 0.00 & 4000.0 \\
\hline $\mathrm{HO}_{2}+\mathrm{HO}_{2} \leftrightarrow \mathrm{H}_{2} \mathrm{O}_{2}+\mathrm{O}_{2}$ & & $k\left(\mathrm{HO}_{2}+\mathrm{I}\right.$ & & & $9.00 \mathrm{E}-11$ & 0.00 & 20000.0 \\
\hline $\mathrm{H}_{2} \mathrm{O}_{2}+\mathrm{OH} \leftrightarrow \mathrm{HO}_{2}+\mathrm{H}_{2} \mathrm{O}$ & & $2.09 \mathrm{E}-13$ & 0.47 & 179.8 & $4.65 \mathrm{E}-11$ & 0.00 & 16500.0 \\
\hline $\mathrm{H}_{2} \mathrm{O}_{2}+\mathrm{H} \leftrightarrow \mathrm{H}_{2} \mathrm{O}+\mathrm{OH}$ & & $4.00 \mathrm{E}-11$ & 0.00 & 2000.0 & & & \\
\hline $\mathrm{N}_{2}+\mathrm{M} \leftrightarrow \mathrm{N}+\mathrm{N}+\mathrm{M}$ & & 7343.0 & -3.00 & 113200.0 & $3.38 \mathrm{E}-32$ & 0.00 & 331.2 \\
\hline $\mathrm{N}+\mathrm{O}_{2} \leftrightarrow \mathrm{NO}+\mathrm{O}$ & & $1.28 \mathrm{E}-11$ & 0.00 & 3562.0 & $3.00 \mathrm{E}-15$ & 0.00 & 19500.0 \\
\hline $\mathrm{N}+\mathrm{OH} \leftrightarrow \mathrm{NO}+\mathrm{H}$ & & $3.80 \mathrm{E}-11$ & 0.00 & -85.0 & $2.80 \mathrm{E}-10$ & 0.00 & 24560.0 \\
\hline $\mathrm{N}+\mathrm{HO}_{2} \leftrightarrow \mathrm{NO}+\mathrm{OH}$ & & $1.66 \mathrm{E}-11$ & 0.00 & 1000.0 & $4.48 \mathrm{E}-12$ & 0.00 & 41630.0 \\
\hline $\mathrm{N}+\mathrm{CO}_{2} \leftrightarrow \mathrm{NO}+\mathrm{CO}$ & & $3.15 \mathrm{E}-13$ & 0.00 & 1710.0 & & & \\
\hline $\mathrm{N}+\mathrm{NO} \leftrightarrow \mathrm{N}_{2}+\mathrm{O}$ & & $3.10 \mathrm{E}-11$ & 0.00 & 0.0 & $1.66 \mathrm{E}-10$ & 0.00 & 37988.0 \\
\hline $\mathrm{N}+\mathrm{NO}_{2} \leftrightarrow \mathrm{NO}+\mathrm{NO}$ & & $2.00 \mathrm{E}-12$ & 0.00 & 0.0 & & & \\
\hline $\mathrm{N}+\mathrm{NO}_{2} \leftrightarrow \mathrm{N}_{2}+\mathrm{O}_{2}$ & & $5.00 \mathrm{E}-13$ & 0.00 & 0.0 & & & \\
\hline $\mathrm{N}+\mathrm{NO}_{2} \leftrightarrow \mathrm{N}_{2} \mathrm{O}+\mathrm{O}$ & & $3.00 \mathrm{E}-12$ & 0.00 & 0.0 & & & \\
\hline
\end{tabular}


Table I. (Continued)

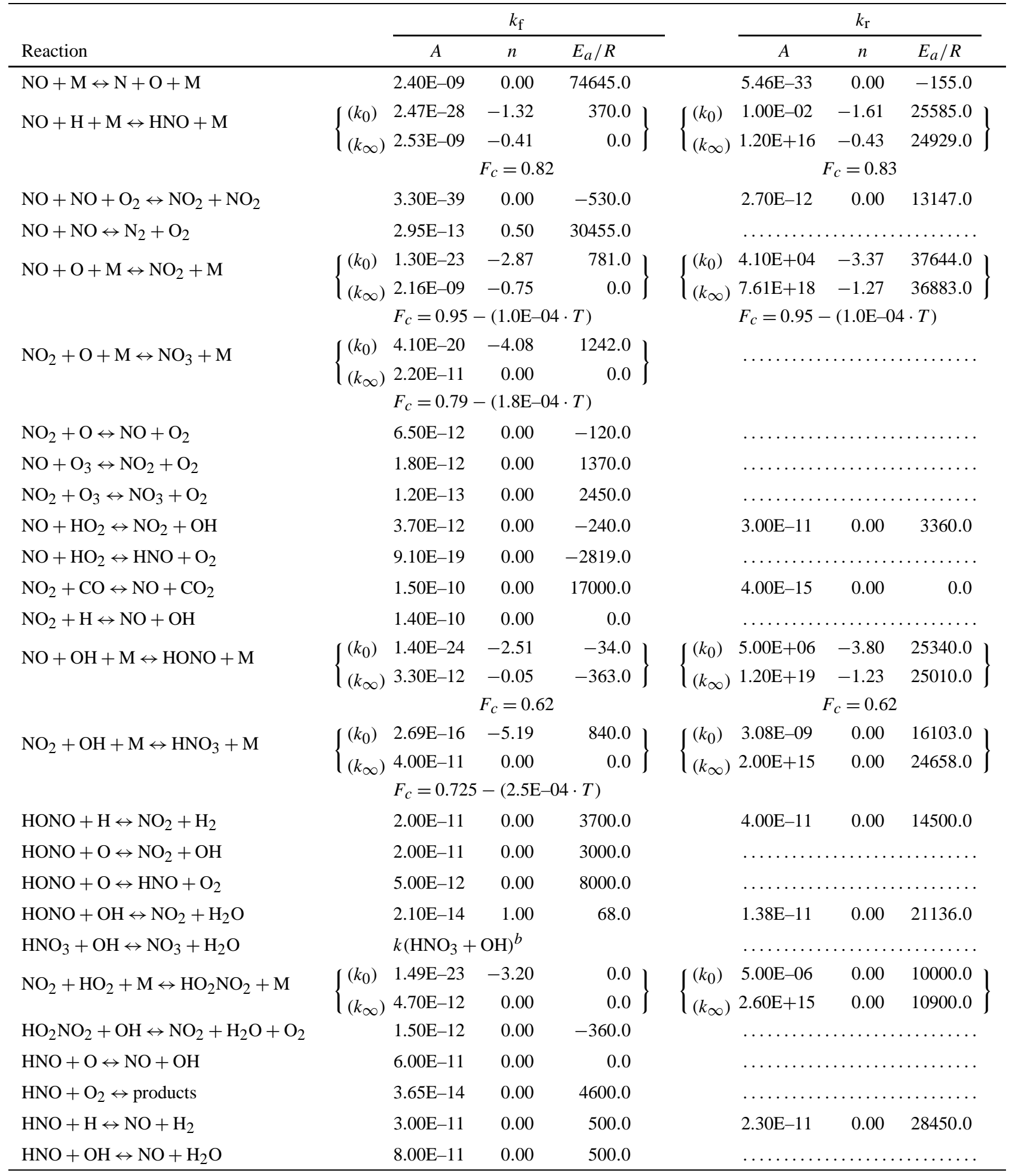


Table I. (Continued)

\begin{tabular}{|c|c|c|c|c|c|c|c|c|}
\hline \multirow[b]{2}{*}{ Reaction } & & \multicolumn{3}{|c|}{$k_{\mathrm{f}}$} & & \multicolumn{3}{|c|}{$k_{\mathrm{r}}$} \\
\hline & & $A$ & $n$ & $E_{a} / R$ & & $A$ & $n$ & $E_{a} / R$ \\
\hline $\mathrm{HNO}+\mathrm{NO} \leftrightarrow \mathrm{N}_{2} \mathrm{O}+\mathrm{OH}$ & & $3.30 \mathrm{E}-12$ & 0.00 & 13083.0 & & $1.96 \mathrm{E}-28$ & 4.33 & 12623 \\
\hline $\mathrm{HNO}+\mathrm{NO}_{2} \leftrightarrow \mathrm{HONO}+\mathrm{NO}$ & & $1.00 \mathrm{E}-12$ & 0.00 & 1000.0 & & & & \\
\hline $\mathrm{HNO}+\mathrm{HNO} \leftrightarrow \mathrm{N}_{2} \mathrm{O}+\mathrm{H}_{2} \mathrm{O}$ & & $1.40 \mathrm{E}-15$ & 0.00 & 1561.0 & & & & \\
\hline \multirow[t]{2}{*}{$\mathrm{N}_{2} \mathrm{O}+\mathrm{M} \leftrightarrow \mathrm{N}_{2}+\mathrm{O}+\mathrm{M}$} & $\left\{\begin{array}{l}\left(k_{0}\right) \\
\left(k_{\infty}\right)\end{array}\right.$ & $\begin{array}{l}1.20 \mathrm{E}-06 \\
1.30 \mathrm{E}+11\end{array}$ & $\begin{array}{r}-0.73 \\
0.00\end{array}$ & $\begin{array}{l}31600.0 \\
30000.0\end{array}$ & & $4.00 \mathrm{E}-38$ & 0.00 & 0.0 \\
\hline & & \multicolumn{3}{|c|}{$F_{c}=1.167-(1.25 \mathrm{E}-04 \cdot T)$} & & & & \\
\hline $\mathrm{N}_{2} \mathrm{O}+\mathrm{O} \leftrightarrow \mathrm{NO}+\mathrm{NO}$ & & $1.10 \mathrm{E}-10$ & 0.00 & 13400.0 & & $6.00 \mathrm{E}-12$ & 0.00 & 32900.0 \\
\hline $\mathrm{N}_{2} \mathrm{O}+\mathrm{O} \leftrightarrow \mathrm{N}_{2}+\mathrm{O}_{2}$ & & $1.70 \mathrm{E}-10$ & 0.00 & 14100.0 & & & & \\
\hline $\mathrm{N}_{2} \mathrm{O}+\mathrm{NO} \leftrightarrow \mathrm{NO}_{2}+\mathrm{N}_{2}$ & & $1.91 \mathrm{E}-10$ & 0.00 & 24800.0 & & & & \\
\hline $\mathrm{N}_{2} \mathrm{O}+\mathrm{H} \leftrightarrow \mathrm{N}_{2}+\mathrm{OH}$ & & $1.60 \mathrm{E}-10$ & 0.00 & 7600.0 & & $5.31 \mathrm{E}-12$ & 0.00 & 40509.0 \\
\hline $\mathrm{N}_{2} \mathrm{O}+\mathrm{OH} \leftrightarrow \mathrm{N}_{2}+\mathrm{HO}_{2}$ & & $1.05 \mathrm{E}-12$ & 0.00 & 5000.0 & & & & \\
\hline $\mathrm{N}_{2} \mathrm{O}+\mathrm{CO} \leftrightarrow \mathrm{N}_{2}+\mathrm{CO}_{2}$ & & $5.30 \mathrm{E}-13$ & 0.00 & 10230.0 & & & & \\
\hline $\mathrm{NO}_{3}+\mathrm{H} \leftrightarrow \mathrm{NO}_{2}+\mathrm{OH}$ & & $9.40 \mathrm{E}-11$ & 0.00 & 0.0 & & & & \\
\hline $\mathrm{NO}_{3}+\mathrm{O} \leftrightarrow \mathrm{NO}_{2}+\mathrm{O}_{2}$ & & $1.70 \mathrm{E}-11$ & 0.00 & 0.0 & & & & \\
\hline $\mathrm{NO}_{3}+\mathrm{OH} \leftrightarrow \mathrm{NO}_{2}+\mathrm{HO}_{2}$ & & $2.00 \mathrm{E}-11$ & 0.00 & 0.0 & & & & \\
\hline $\mathrm{NO}_{3}+\mathrm{HO}_{2} \leftrightarrow \mathrm{NO}_{2}+\mathrm{OH}+\mathrm{O}_{2}$ & & $3.00 \mathrm{E}-12$ & 0.00 & 0.0 & & & & \\
\hline $\mathrm{NO}_{3}+\mathrm{HO}_{2} \leftrightarrow \mathrm{HNO}_{3}+\mathrm{O}_{2}$ & & $5.00 \mathrm{E}-13$ & 0.00 & 0.0 & & & & \\
\hline $\mathrm{NO}_{3}+\mathrm{NO} \leftrightarrow \mathrm{NO}_{2}+\mathrm{NO}_{2}$ & & $1.80 \mathrm{E}-11$ & 0.00 & -110.0 & & $1.60 \mathrm{E}-14$ & 0.73 & 10530.0 \\
\hline $\mathrm{NO}_{3}+\mathrm{NO}_{2} \leftrightarrow \mathrm{NO}+\mathrm{NO}_{2}+\mathrm{O}_{2}$ & & $4.50 \mathrm{E}-14$ & 0.00 & 1260.0 & & & & \\
\hline \multirow{3}{*}{$\mathrm{NO}_{3}+\mathrm{NO}_{2}+\mathrm{M} \leftrightarrow \mathrm{N}_{2} \mathrm{O}_{5}+\mathrm{M}$} & $\int\left(k_{0}\right)$ & $7.00 \mathrm{E}-22$ & -3.40 & 0.0 & $\int\left(k_{0}\right)$ & $4.68 \mathrm{E}+05$ & -3.50 & 11000.0 \\
\hline & $\left\{\left(k_{\infty}\right)\right.$ & $6.40 \mathrm{E}-13$ & 0.20 & 0.0 & $\left(k_{\infty}\right)$ & $5.49 \mathrm{E}+14$ & 0.10 & 11080.0 \\
\hline & & \multicolumn{3}{|c|}{$F_{c}=\exp (-T / 250)+\exp (-1050 / T)$} & & \multicolumn{3}{|c|}{$F_{c}=\exp (-T / 250)+\exp (-1050 / T)$} \\
\hline \multicolumn{2}{|l|}{$\mathrm{N}_{2} \mathrm{O}_{5}+\mathrm{H}_{2} \mathrm{O} \leftrightarrow \mathrm{HNO}_{3}+\mathrm{HNO}_{3}$} & $1.50 \mathrm{E}-21$ & 0.00 & 0.0 & & & & \\
\hline \multicolumn{2}{|l|}{$\mathrm{CO}+\mathrm{O}+\mathrm{M} \leftrightarrow \mathrm{CO}_{2}+\mathrm{M}$} & $1.70 \mathrm{E}-33$ & 0.00 & 1510.0 & & $4.17 \mathrm{E}-11$ & 0.00 & 43780.0 \\
\hline \multicolumn{2}{|l|}{$\mathrm{CO}+\mathrm{O}_{2} \leftrightarrow \mathrm{CO}_{2}+\mathrm{O}$} & $4.20 \mathrm{E}-12$ & 0.00 & 24000.0 & & $2.80 \mathrm{E}-11$ & 0.00 & 26500.0 \\
\hline \multicolumn{2}{|l|}{$\mathrm{CO}+\mathrm{OH} \leftrightarrow \mathrm{CO}_{2}+\mathrm{H}$} & $1.05 \mathrm{E}-17$ & 1.50 & -250.0 & & $2.50 \mathrm{E}-10$ & 0.00 & 13300.0 \\
\hline \multicolumn{2}{|l|}{$\mathrm{CO}+\mathrm{HO}_{2} \leftrightarrow \mathrm{CO}_{2}+\mathrm{OH}$} & $2.50 \mathrm{E}-10$ & 0.00 & 11900.0 & & & & \\
\hline \multicolumn{2}{|l|}{$\mathrm{SO}+\mathrm{O}+\mathrm{M} \leftrightarrow \mathrm{SO}_{2}+\mathrm{M}$} & $3.30 \mathrm{E}-26$ & -1.84 & 0.0 & & $5.89 \mathrm{E}-10$ & 0.00 & 52801.0 \\
\hline \multicolumn{2}{|l|}{$\mathrm{SO}+\mathrm{O}_{2} \leftrightarrow \mathrm{SO}_{2}+\mathrm{O}$} & $1.40 \mathrm{E}-13$ & 0.00 & 2280.0 & & $8.30 \mathrm{E}-12$ & 0.00 & 9800.0 \\
\hline \multicolumn{2}{|l|}{$\mathrm{SO}+\mathrm{O}_{3} \leftrightarrow \mathrm{SO}_{2}+\mathrm{O}_{2}$} & $4.50 \mathrm{E}-12$ & 0.00 & 1170.0 & & & & \\
\hline \multicolumn{2}{|l|}{$\mathrm{SO}+\mathrm{OH} \leftrightarrow \mathrm{SO}_{2}+\mathrm{H}$} & $8.59 \mathrm{E}-11$ & 0.00 & 0.0 & & & & \\
\hline \multicolumn{2}{|l|}{$\mathrm{SO}+\mathrm{SO}_{3} \leftrightarrow \mathrm{SO}_{2}+\mathrm{SO}_{2}$} & $2.00 \mathrm{E}-15$ & 0.00 & 0.0 & & & & \\
\hline \multicolumn{2}{|l|}{$\mathrm{SO}+\mathrm{NO}_{2} \leftrightarrow \mathrm{SO}_{2}+\mathrm{NO}$} & $1.40 \mathrm{E}-11$ & 0.00 & 0.0 & & & & \\
\hline \multirow{2}{*}{$\mathrm{SO}_{2}+\mathrm{OH}+\mathrm{M} \leftrightarrow \mathrm{HSO}_{3}+\mathrm{M}$} & $\int\left(k_{0}\right)$ & $1.97 \mathrm{E}-32$ & 0.00 & $-867.3\}$ & & & & \\
\hline & $\left\{\left(k_{\infty}\right)\right.$ & $2.00 \mathrm{E}-12$ & 0.00 & 0.0 & & & & \\
\hline \multicolumn{2}{|l|}{$\mathrm{HSO}_{3}+\mathrm{O}_{2} \leftrightarrow \mathrm{SO}_{3}+\mathrm{HO}_{2}$} & $1.30 \mathrm{E}-12$ & 0.00 & 330.0 & & & & \\
\hline
\end{tabular}


Table I. (Continued)

\begin{tabular}{|c|c|c|c|c|c|c|}
\hline \multirow[b]{2}{*}{ Reaction } & \multicolumn{3}{|c|}{$k_{\mathrm{f}}$} & \multicolumn{3}{|c|}{$k_{\mathrm{r}}$} \\
\hline & $A$ & $n$ & $E_{a} / R$ & $A$ & $n$ & $E_{a} / R$ \\
\hline $\mathrm{SO}_{2}+\mathrm{O}+\mathrm{M} \leftrightarrow \mathrm{SO}_{3}+\mathrm{M}$ & $4.00 \mathrm{E}-32$ & 0.00 & 1000.0 & $5.25 \mathrm{E}-09$ & 0.00 & 31873.0 \\
\hline $\mathrm{SO}_{2}+\mathrm{HO}_{2} \leftrightarrow \mathrm{SO}_{3}+\mathrm{OH}$ & $1.00 \mathrm{E}-18$ & 0.00 & 0.0 & & & \\
\hline $\mathrm{SO}_{2}+\mathrm{NO}_{2} \leftrightarrow \mathrm{SO}_{3}+\mathrm{NO}$ & $1.05 \mathrm{E}-11$ & 0.00 & 13587.0 & & & \\
\hline $\mathrm{SO}_{2}+\mathrm{O}_{3} \leftrightarrow \mathrm{SO}_{3}+\mathrm{O}_{2}$ & $3.00 \mathrm{E}-12$ & 0.00 & 7000.0 & & & \\
\hline $\mathrm{SO}_{2}+\mathrm{CH}_{3} \mathrm{O}_{2} \leftrightarrow \mathrm{SO}_{3}+\mathrm{CH}_{3} \mathrm{O}$ & $4.00 \mathrm{E}-17$ & 0.00 & 0.0 & & & \\
\hline $\mathrm{SO}_{3}+\mathrm{O} \leftrightarrow \mathrm{SO}_{2}+\mathrm{O}_{2}$ & $2.19 \mathrm{E}-12$ & 0.00 & 3070.0 & & & \\
\hline $\mathrm{SO}_{3}+\mathrm{H}_{2} \mathrm{O}+\mathrm{M} \leftrightarrow \mathrm{H}_{2} \mathrm{SO}_{4}+\mathrm{M}$ & $1.20 \mathrm{E}-15$ & 0.00 & 0.0 & $\ldots$ & 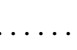 & $\ldots \ldots \ldots$ \\
\hline
\end{tabular}

Rate constants $k$ are given in the form $k(T)=A \cdot T^{n} \cdot \exp \left(-E_{a} / R T\right) . k_{f}$ denotes the rate constant for the forward reaction, $k_{r}$ for the reverse reaction. For some termolecular or unimolecular reactions, $k_{0}$ is the low pressure limit and $k_{\infty}$ is the high pressure limit of the effective second- or first-order rate constant $k$ :

$$
k=\left(k_{0} \cdot[\mathrm{M}] /\left(1+k_{0} \cdot[\mathrm{M}] / k_{\infty}\right)\right) \cdot F_{c}^{\left(1+\left(\log _{10}\left(k_{0} \cdot[\mathrm{M}] / k_{\infty}\right)\right)^{2}\right)^{-1}}
$$

(Troe equation)

where $F_{c}=0.6$, unless otherwise noted. Units: $\mathrm{s}^{-1}$ for unimolecular, $\mathrm{cm}^{3}$ molecule ${ }^{-1} \mathrm{~s}^{-1}$ for bimolecular, and $\mathrm{cm}^{6}$ molecule $\mathrm{s}^{-2} \mathrm{~s}^{-1}$ for termolecular rate constants.

$a_{k}\left(\mathrm{HO}_{2}+\mathrm{HO}_{2}\right)=[2.3 \mathrm{E}-13 \cdot \exp (600 / T)+1.7 \mathrm{E}-33 \cdot[\mathrm{M}] \cdot \exp (1000 / T)] \cdot\left[1+1.4 \mathrm{E}-21 \cdot\left[\mathrm{H}_{2} \mathrm{O}\right] \cdot \exp (2200 / T)\right]$

${ }^{b} k\left(\mathrm{HNO}_{3}+\mathrm{OH}\right)=k_{0}+\left(k_{3} \cdot[\mathrm{M}] /\left(1+\left(k_{3} \cdot[\mathrm{M}] / k_{2}\right)\right)\right)$, with $k_{0}=7.2 \mathrm{E}-15 \cdot \exp (785 / T), k_{2}=4.1 \mathrm{E}-16 \cdot \exp (1440 / T), k_{3}=$ $1.9 \mathrm{E}-33 \cdot \exp (725 / T)$

ary model conditions corresponding to a case study described in [40] (B747 exhaust plume encounter measurements, encounter P5/2). The thermodynamic engine parameters were derived from engine calculations for this engine with the measured conditions (Deidewig, personal communication, 1996). The most important parameters are listed in the following text. The simulations start at the combustor exit at the temperature $T \approx 1200 \mathrm{~K}$ and pressure $p \approx 7700 \mathrm{hPa}$, decreasing to $T=621 \mathrm{~K}$ (linear decrease) and $p=301 \mathrm{hPa}$ (fast decrease following a hyperbolic function) after $3.5 \mathrm{~ms}$ at the nozzle exit. The initial mixing ratio of $\mathrm{NO}_{x}$ at the combustor exit amounts to $276 \mathrm{ppmv}$ (this corresponds to $\mathrm{EI}\left(\mathrm{NO}_{x}\right)=$ $26.8 \mathrm{~g}\left(\mathrm{NO}_{2}\right.$-equivalents $) /(\mathrm{kg}$ fuel $\left.)\right)$, with $\mathrm{NO}_{2} / \mathrm{NO}_{x}=$ $15.9 \%$. The initial mixing ratio of $\mathrm{OH}$ for this case is $9.5 \mathrm{ppmv}(\mathrm{EI}(\mathrm{OH})=0.34 \mathrm{~g} / \mathrm{kg})$, and that of $\mathrm{SO}_{2}$ is 1.27 ppmv $\left(\mathrm{EI}\left(\mathrm{SO}_{2}\right)=0.17 \mathrm{~g} / \mathrm{kg}\right)$. The scenario with these initial conditions and using the reaction rate constants as listed in table I serves as a reference simulation for the sensitivity studies and is designated as the 'baseline scenario' in the subsequent text. The initial mixing ratios of the chemical products $\mathrm{HNO}_{2}, \mathrm{HNO}_{3}, \mathrm{SO}_{3}$ and $\mathrm{H}_{2} \mathrm{SO}_{4}$ are assumed to be zero at the combustor exit. Thus, conversion efficiencies stated in this paper refer to the 'additional' oxidation behind the combustor. The initial mixing ratio of $\mathrm{O}$ for the baseline case was estimated with an equilibrium calculation, yielding $\mathrm{O} / \mathrm{OH} \approx 2 \%$. This equilibrium calculation was performed by a model run with the conditions at the combustor exit. Since the equilibrium between $\mathrm{O}$ and $\mathrm{OH}$ is reached in 10-100 $\mu$ s, this equilibrium ratio should be a reasonable estimate of the real ratio. Our $\mathrm{O} / \mathrm{OH}$ ratio agrees very well with that used by Lukachko et al. [33].

\section{Results of the sensitivity studies}

\subsection{Baseline scenario}

The evolution of the mixing ratios of $\mathrm{SO}_{2}, \mathrm{OH}, \mathrm{SO}_{3}$, and $\mathrm{H}_{2} \mathrm{SO}_{4}$ as a result of a model simulation for the JT9D-7A baseline case (see section 2) is shown in figure 1. First, there is a built-up of $\mathrm{SO}_{3}$ behind the combustor exit at time scales below $1 \mathrm{~ms}$, and after a few milliseconds, the production of $\mathrm{H}_{2} \mathrm{SO}_{4}$ is prevailing. For the baseline scenario in figure 1, the nozzle exit is $3.5 \mathrm{~ms}$ after the start of the simulation (combustor exit), and shortly thereafter the dilution behind the engine exit becomes noticeable. The efficiency $\varepsilon$ of the fuel-sulfur conversion to $\mathrm{SO}_{3}$ and $\mathrm{H}_{2} \mathrm{SO}_{4}\left(\varepsilon=\left(\left[\mathrm{SO}_{3}\right]+\right.\right.$ $\left.\left.\left[\mathrm{H}_{2} \mathrm{SO}_{4}\right]\right) /\left[\mathrm{SO}_{x}\right]\right)$ ) for this baseline case, plotted in figure 2 , increases to an equilibrium value of $3.81 \%$ after a few milliseconds. Most of the conversions take place within the engine before the exhaust gas leaves the engine exit [40].

To determine the influence of the model parameters on the efficiency $\varepsilon$ of fuel-sulfur conversion, we performed several sensitivity studies (section 3.2 and 3.3 ) by solely varying each of the corresponding parameters within a realistic range and using the same values as in the baseline case for all remaining parameters. 


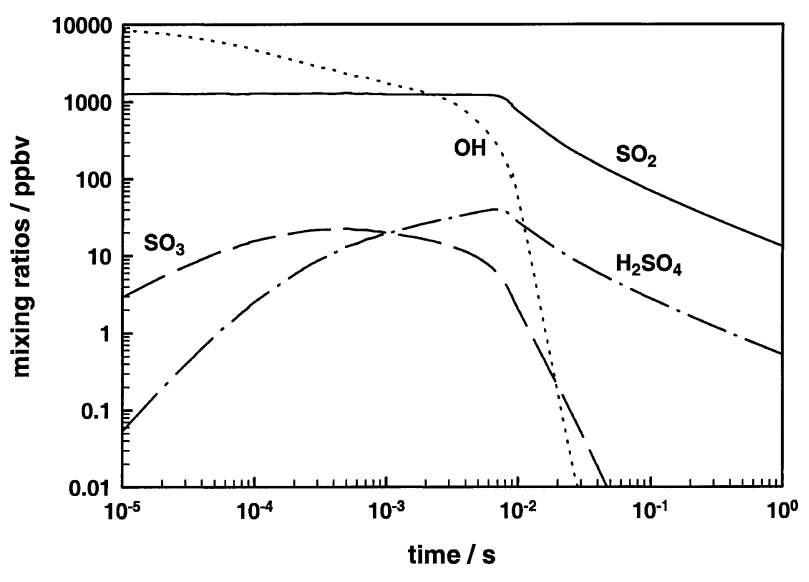

Figure 1. Evolution of the mixing ratios of $\mathrm{SO}_{2}, \mathrm{OH}, \mathrm{SO}_{3}$, and $\mathrm{H}_{2} \mathrm{SO}_{4}$ as a result of the model simulation for the JT9D-7A baseline case.

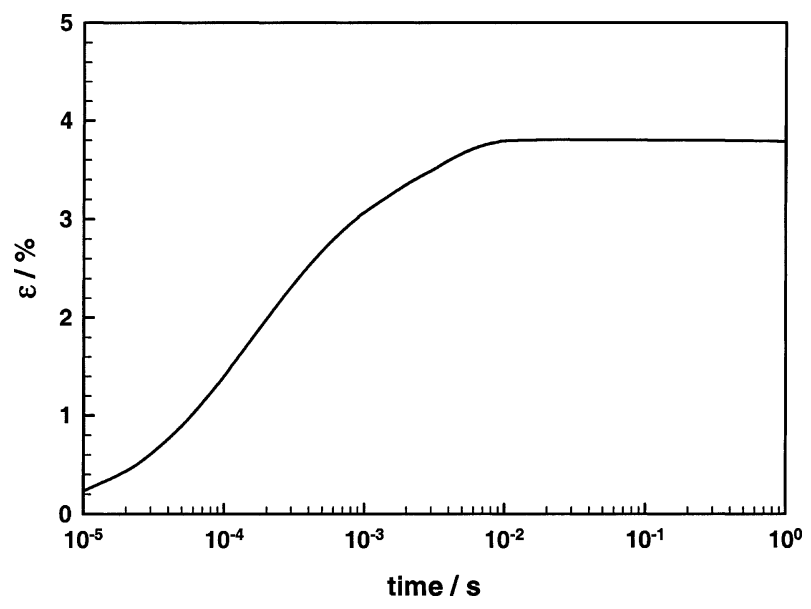

Figure 2. Evolution of the efficiency $\varepsilon$ of the fuel-sulfur conversion to $\mathrm{SO}_{3}$ and $\left.\mathrm{H}_{2} \mathrm{SO}_{4}\left(\varepsilon=\left(\left[\mathrm{SO}_{3}\right]+\left[\mathrm{H}_{2} \mathrm{SO}_{4}\right]\right) /\left[\mathrm{SO}_{x}\right]\right)\right)$ for the baseline case (plotted in figure 1).

\subsection{Effects of uncertainties of the reaction rate constants}

There are only a few reactions of the chemistry code (cf. table I) that effectively control the fuel-sulfur conversion efficiency. These reactions have been identified by numerous test simulations. Thus, the sensitivities of the uncertainties of the rate constants on $\varepsilon$ have been determined only for these equations. Of course, the $\mathrm{SO}_{x}$ reactions listed in the introduction are probably the most important, and their influence will be discussed below. But there are some additional reactions of the $\mathrm{HO}_{x}$ and $\mathrm{NO}_{x}$ cycle like the $\mathrm{OH}$ self reactions and $\mathrm{OH}$ reactions with $\mathrm{NO}_{x}$, listed in table II, which are important as well. The uncertainty ranges of the rate constants $k$ have been derived from the NIST data base for temperatures around $1000 \mathrm{~K}$. For some reactions, this range exceeds one order of magnitude (see table II). The effect on $\varepsilon$ has been tested with simulations using the respective minimum and maximum reaction rate constant.

First, we want to discuss the influence of the $\mathrm{HO}_{x}$ and $\mathrm{NO}_{x}$ reactions on $\varepsilon$. The overall range of $\varepsilon$ resulting from the uncertainty of these rate constants varies between $3.52 \%$ and $4.09 \%$, i.e., $\varepsilon=(3.81 \pm 0.29) \%$, or $\pm 7.6 \%$ relatively (see table II). Considering the large uncertainties of some of these rate constants, the effect on $\varepsilon$ is relatively small. The magnitude of the sensitivity and the resulting range of $\varepsilon$ depends on a combination of several factors, e.g., the range of uncertainty of $k$, the absolute value of $k$, and the concentration of the reacting species. Concerning the $\mathrm{HO}_{x}$ and $\mathrm{NO}_{x}$ reactions, the uncertainty of the rate constant of reaction $\mathrm{OH}+\mathrm{NO}+\mathrm{M} \rightarrow \mathrm{HNO}_{2}+\mathrm{M}$ has the greatest effect on $\varepsilon$, followed by $\mathrm{OH}+\mathrm{OH} \rightarrow \mathrm{O}+\mathrm{H}_{2} \mathrm{O}$. The effect of the reverse reactions of the $\mathrm{HNO}_{2}$ and $\mathrm{HNO}_{3}$ production is insignificant $(< \pm 0.03 \%$ absolute, or $< \pm 1 \%$ relative, respectively; see table II).

The main $\mathrm{SO}_{x}$ reactions that control the fuel-sulfur conversion efficiency $\varepsilon$ are $\mathrm{SO}_{2}+\mathrm{OH}+\mathrm{M} \rightarrow \mathrm{HSO}_{3}+\mathrm{M}$ and $\mathrm{SO}_{2}+\mathrm{O}+\mathrm{M} \rightarrow \mathrm{SO}_{3}+\mathrm{M}$. On the other hand, the conversion efficiency is insensitive to the magnitude of the rate constants of the subsequent reactions $\mathrm{HSO}_{3}+$ $\mathrm{O}_{2} \rightarrow \mathrm{SO}_{3}+\mathrm{HO}_{2}$ and $\mathrm{SO}_{3}+\mathrm{H}_{2} \mathrm{O}+\mathrm{M} \rightarrow \mathrm{H}_{2} \mathrm{SO}_{4}+\mathrm{M}$ : variations between $0.01 k$ and $100 k$, as a coarse test, show no impact on $\varepsilon$.

The reaction $\mathrm{SO}_{2}+\mathrm{OH}+\mathrm{M} \rightarrow \mathrm{HSO}_{3}+\mathrm{M}$ has the greatest effect on $\varepsilon$ (see table II and III). As this reaction is termolecular, its effective bimolecular rate constant is calculated from a termolecular low-pressure value $k_{0}$ and a bimolecular high-pressure value $k_{\infty}$ via the Troe expression (see footnote in table I). The rate constants $k_{0}$ and $k_{\infty}$ are extracted from the NIST data base [34] which comprises a large body of published data, and are plotted in figures 3 and 4 , respectively. The uncertainty ranges of $k_{0}$ and $k_{\infty}$ are derived from these data. Apart from one theoretical study [11], all data are only available for a temperature range up to $450 \mathrm{~K}$. Thus, the temperature dependencies of $k_{0}$ and $k_{\infty}$ have to be extrapolated to higher temperatures, leading to a broad uncertainty range around $1000 \mathrm{~K}$. The lower and upper limits of $k_{0}$ and $k_{\infty}$ for $\mathrm{SO}_{2}+\mathrm{OH}$ are listed in table III. The lower and upper limits of the rate constant $k\left(\mathrm{SO}_{2}+\mathrm{OH}\right)$ are calculated from the respective limits of $k_{0}$ and $k_{\infty}$. For our sensitivity studies we have excluded estimated rate constant data and measurements of $k$ using bath gases (M) like $\mathrm{SO}_{2}, \mathrm{He}, \mathrm{Ar}$, and $\mathrm{SF}_{6}$ (see figures 3 and 4), because these data are presumably not applicable for our intra-engine and atmospheric conditions, where $\mathrm{N}_{2}$ and $\mathrm{O}_{2}$ dominate as inert reactants $\mathrm{M}$. The uncertainty range of the rate constant at $7700 \mathrm{hPa}$ and $1200 \mathrm{~K}$ (JT9D$7 \mathrm{~A}$ combustor exit condition) amounts to $9.23 \cdot 10^{-14}$ $\mathrm{cm}^{3}$ molecule ${ }^{-1} \mathrm{~s}^{-1}<k<9.27 \cdot 10^{-13} \mathrm{~cm}^{3}$ molecule $^{-1}$ $\mathrm{s}^{-1}$ (see table III). For comparison, the reference value for the baseline case is $k(7700 \mathrm{hPa}, 1200 \mathrm{~K})=5.83$. $10^{-13} \mathrm{~cm}^{3}$ molecule $\mathrm{s}^{-1} \mathrm{~s}^{-1}$ (calculated from $k_{0}$ and $k_{\infty}$ 
Table II. Variability of $\varepsilon$ resulting from uncertainties of the reaction rate constants $k$.

\begin{tabular}{|c|c|c|}
\hline Reaction & Uncertainty range of $k$ & Range of $\varepsilon$ \\
\hline $\mathrm{OH}+\mathrm{OH} \rightarrow \mathrm{O}+\mathrm{H}_{2} \mathrm{O}$ & $0.5 k_{\mathrm{ref}}-1.5 k_{\mathrm{ref}}$ & $3.59 \%-4.08 \%$ \\
\hline $\mathrm{O}+\mathrm{H}_{2} \mathrm{O} \rightarrow \mathrm{OH}+\mathrm{OH}$ & $0.5 k_{\mathrm{ref}}-1.5 k_{\mathrm{ref}}$ & $3.60 \%-3.93 \%$ \\
\hline $\mathrm{OH}+\mathrm{OH}+\mathrm{M} \rightarrow \mathrm{H}_{2} \mathrm{O}_{2}+\mathrm{M}$ & $0.1 k_{\mathrm{ref}}-5 k_{\mathrm{ref}}$ & $3.61 \%-3.86 \%$ \\
\hline $\mathrm{OH}+\mathrm{NO}+\mathrm{M} \rightarrow \mathrm{HNO}_{2}+\mathrm{M}$ & $0.5 k_{\mathrm{ref}}-2 k_{\mathrm{ref}}$ & $3.52 \%-4.09 \%$ \\
\hline $\mathrm{OH}+\mathrm{NO}_{2}+\mathrm{M} \rightarrow \mathrm{HNO}_{3}+\mathrm{M}$ & $0.3 k_{\mathrm{ref}}-3 k_{\mathrm{ref}}$ & $3.66 \%-3.89 \%$ \\
\hline $\mathrm{HNO}_{2}+\mathrm{M} \rightarrow \mathrm{OH}+\mathrm{NO}+\mathrm{M}$ & $0.7 k_{\mathrm{ref}}-1.3 k_{\mathrm{ref}}$ & $3.78 \%-3.83 \%$ \\
\hline $\mathrm{HNO}_{3}+\mathrm{M} \rightarrow \mathrm{OH}+\mathrm{NO}_{2}+\mathrm{M}$ & $0.5 k_{\text {ref }}-2 k_{\text {ref }}$ & $3.80 \%-3.81 \%$ \\
\hline $\mathrm{SO}_{2}+\mathrm{O}+\mathrm{M} \rightarrow \mathrm{SO}_{3}+\mathrm{M}$ & $0.3 k_{\mathrm{ref}}-3 k_{\mathrm{ref}}$ & $3.75 \%-3.96 \%$ \\
\hline $\mathrm{SO}_{2}+\mathrm{OH}+\mathrm{M} \rightarrow \mathrm{HSO}_{3}+\mathrm{M}$ & $0.16 k_{\mathrm{ref}}-1.6 k_{\mathrm{ref}}$ & $1.07 \%-6.17 \%^{a}$ \\
\hline
\end{tabular}

$k_{\text {ref }}$ denotes the reference rate constant (listed in table $I$ ) for the respective reaction.

${ }^{a}$ for details, see table III

Table III. Lower and upper limits of $\varepsilon$ resulting from the uncertainty of the reaction rate constant $k\left(\mathrm{SO}_{2}+\mathrm{OH}\right) . k$ is calculated from $k_{0}$ and $k_{\infty}$ via the Troe expression (see footnote in table I). The value of $k$ for $7700 \mathrm{hPa}$ and $1200 \mathrm{~K}$ (JT9D-7A combustor exit condition) is also listed.

\begin{tabular}{llcl}
\hline & \multicolumn{1}{c}{ lower limit } & reference & \multicolumn{1}{c}{ upper limit } \\
\hline$k_{0}$ & $1.39 \cdot 10^{-33} \cdot \exp (1409 / T)$ & {$[9]$} & $3.92 \cdot 10^{-32} \cdot \exp (867.3 / T)$ \\
$k_{\infty}$ & $6.79 \cdot 10^{-11} \cdot T^{-0.7}$ & {$[43]$} & $2.74 \cdot 10^{-12} \cdot \exp (-80 / T)$ \\
$k(7700 \mathrm{hPa}, 1200 \mathrm{~K})$ & $9.23 \cdot 10^{-14}$ & & $9.27 \cdot 10^{-13}$ \\
\hline$\varepsilon$ & $1.07 \%$ & $6.17 \%$ & {$[11]$} \\
\hline
\end{tabular}

The rate constant data are extracted from the NIST data base [34]. Excluded are estimated values and measurements of $k$ using bath gases like $\mathrm{SO}_{2}, \mathrm{He}, \mathrm{Ar}$, and $\mathrm{SF}_{6}$. Units: $\mathrm{cm}^{6} \cdot$ molecule ${ }^{-2} \cdot \mathrm{s}^{-1}$ for $k_{0}$ (termolecular), and $\mathrm{cm}^{3} \cdot \mathrm{molecule}^{-1} \cdot \mathrm{s}^{-1}$ for $k_{\infty}$ and $k$ (bimolecular or effectively bimolecular, respectively).

${ }^{a}$ Upper limit value only available for $298 \mathrm{~K}\left(k_{0}=7.20 \cdot 10^{-31} \mathrm{~cm}^{6} \cdot\right.$ molecule $\left.{ }^{-2} \cdot \mathrm{s}^{-1}\right)$ [23]; extrapolation to higher temperature using the slope (in the Arrhenius graph) of the fit function (see table I).

from table I, assuming a normal Arrhenius behavior for $k_{0}$, i.e., $n=0$ ), and represents a fit to all NIST data (same expression as used by Kärcher et al. [28]). This uncertainty range of $k\left(\mathrm{SO}_{2}+\mathrm{OH}\right)$ leads to simulated sulfur conversion efficiencies varying between $1.07 \%$ and $6.17 \%$ as listed in table III. If the temperature dependence of the extrapolated $k\left(\mathrm{SO}_{2}+\mathrm{OH}\right)$ would deviate from a normal Arrhenius behavior $(n \neq 0)$, an even larger uncertainty would result. Altogether, we assume that the most reliable value of $\varepsilon$ for our JT9D-7A simulations is around $3.8 \%$ (baseline case).

Although the rate constant $k\left(\mathrm{SO}_{2}+\mathrm{O}\right)$ is of the same order of magnitude as $k\left(\mathrm{SO}_{2}+\mathrm{OH}\right)$, with an uncertainty between about $0.3 k$ and $3 k$, its effect on $\varepsilon$ is very low (see table II; the reverse reaction has no essential effect), because the initial mixing ratio of $\mathrm{O}$ is assumed to be much lower than $\mathrm{OH}$. For our baseline simulations we used an initial $\mathrm{O} / \mathrm{OH}$ ratio of $1 / 50$, derived from equilibrium calculations (see section 2). The effect of the uncertainty and variability of the initial $\mathrm{O} / \mathrm{OH}$ will be discussed in section 3.3.

\subsection{Effects of variations of the initial mixing ratios}

In this section, the influence of the variation of the initial mixing ratios at the combustor exit will be discussed. Considering table II, the most important species influencing the fuel sulfur conversion efficiency should be $\mathrm{SO}_{2}$, $\mathrm{SO}_{3}, \mathrm{OH}, \mathrm{O}, \mathrm{NO}$, and $\mathrm{NO}_{2}$. Their initial mixing ratios are showing great variations or are poorly known, respectively. To determine the effect of the initial mixing ratio of one species on $\varepsilon$, we have varied this value within realistic ranges keeping all remaining initial and boundary values fixed at their respective baseline value (baseline initial mixing ratios for $\mathrm{SO}_{2}, \mathrm{SO}_{3}, \mathrm{OH}, \mathrm{O}, \mathrm{NO}$, and $\mathrm{NO}_{2}$ are mentioned in section 2).

Our simulations show that the variation of the fuelsulfur content (i.e., $\mathrm{EI}\left(\mathrm{SO}_{2}\right)$ ) has only a small effect on $\varepsilon$ (see figure 5): Varying $\mathrm{EI}\left(\mathrm{SO}_{2}\right)$ between $0.01 \mathrm{~g} / \mathrm{kg}$ and $10.0 \mathrm{~g} / \mathrm{kg}$ leads to a slight decrease of $\varepsilon$ from $3.81 \%$ (constant up to $\mathrm{EI}=0.2 \mathrm{~g} / \mathrm{kg}$ ) to $3.54 \%$, with the main decrease above $\mathrm{EI}\left(\mathrm{SO}_{2}\right)=1 \mathrm{~g} / \mathrm{kg}$. Aviation fuel specifications limit the fuel sulfur content to values such that $\mathrm{EI}\left(\mathrm{SO}_{2}\right)$ stays below $6 \mathrm{~g} / \mathrm{kg}$ with a prevailing value 


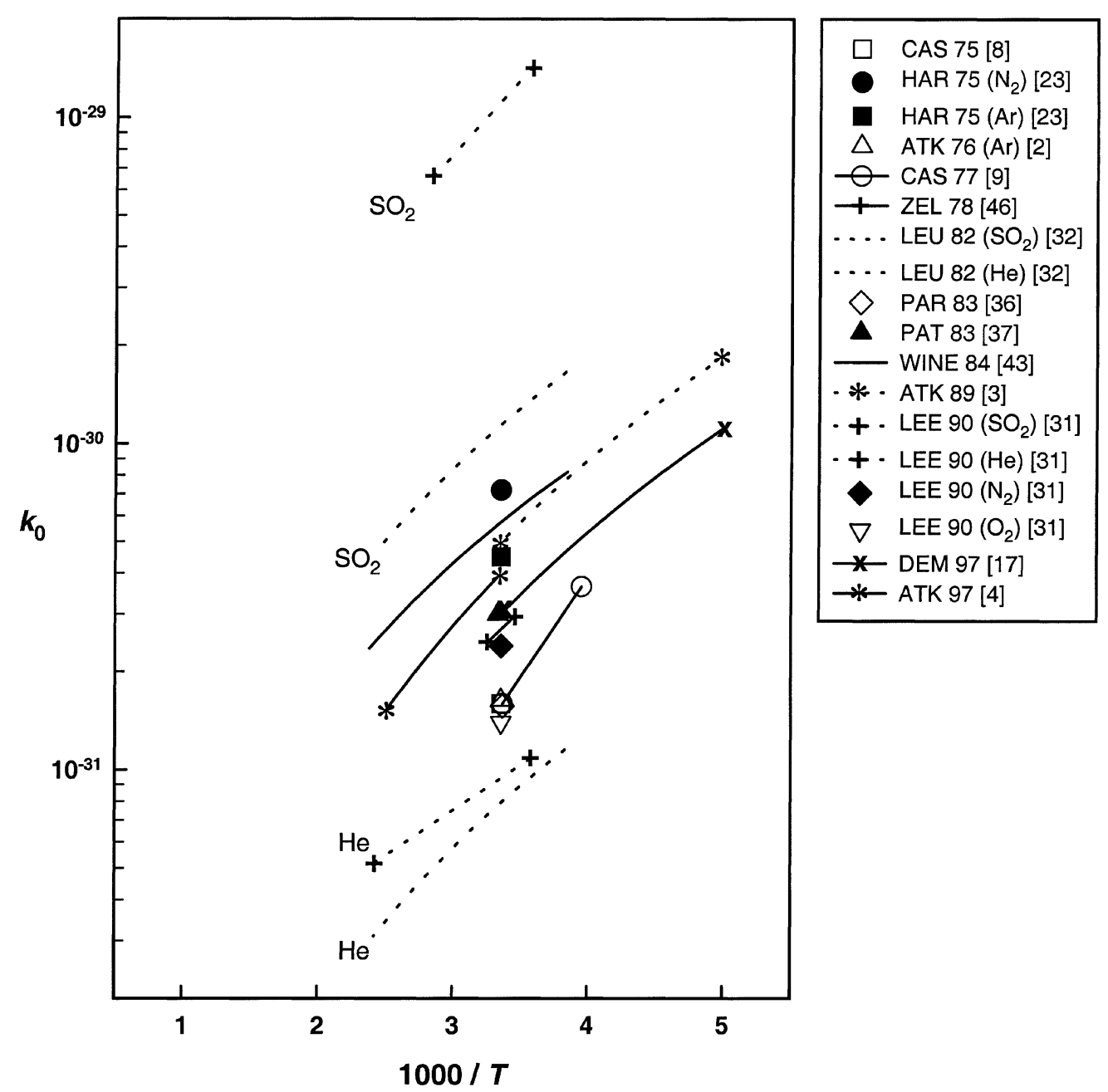

Figure 3. Arrhenius graph of the published data on the low pressure rate constant $k_{0}$ for the reaction $\mathrm{SO}_{2}+\mathrm{OH}+\mathrm{M} \rightarrow \mathrm{HSO} 3+\mathrm{M}$, extracted from the NIST data base [34]. Temperature $T$ is given in $\mathrm{K}$, and $k_{0}$ in $\mathrm{cm}^{6}$ molecule $\mathrm{s}^{-2}$. Acronyms in the legend refer to the corresponding references. Bath gases $\mathrm{M}$ other than $\mathrm{N}_{2}$ are indicated.

around $0.8 \mathrm{~g} / \mathrm{kg}$ [19]. Figure 6 shows the influence of the initial $\mathrm{OH}$ mixing ratio $\left(\mathrm{OH}_{0}\right)$ on the sulfur conversion efficiency. An increase of the initial $\mathrm{OH}$ mixing ratio from 2 up to 100 ppmv (baseline: $9.5 \mathrm{ppmv}$ ) yields an increase of $\varepsilon$ from $1.26 \%$ up to $13.9 \%$, because the oxidized sulfur species mainly form via $\mathrm{SO}_{2}+\mathrm{OH}$. The increase of $\varepsilon$ for increasing $\mathrm{OH}_{0}$ is less than linear (please note that the $x$-axis of figure 6 is given in a logarithmic scale). Since the initial mixing ratio of $\mathrm{OH}$ for the baseline case $\left(\mathrm{OH}_{0}=9.5 \mathrm{ppmv}\right)$ has an uncertainty range between $5.7 \mathrm{ppmv}$ and $14.7 \mathrm{ppmv}$ (inferred from measurements [40]), this results in an uncertainty range of $2.7 \%<\varepsilon<5.0 \%$. In figure 7 , the dependence of $\varepsilon$ on the initial ratio $\mathrm{O} / \mathrm{OH}$ is plotted. If the initial $\mathrm{O}$ exceeds more than $10 \%$ of the initial $\mathrm{OH}$ (baseline initial value: $\mathrm{O} / \mathrm{OH}=2 \%$ ), an effect of the increasing $\mathrm{O}$ on $\varepsilon$ becomes noticeable. Below this value $\varepsilon$ is nearly insensitive to $\mathrm{O}$.
This is an effect of the similar rate constants for $\mathrm{SO}_{2}+$ $\mathrm{OH}$ and $\mathrm{SO}_{2}+\mathrm{O}$ (see section 3.2).

Figure 8 shows the dependence of $\varepsilon$ on $\operatorname{EI}\left(\mathrm{NO}_{x}\right)$ : An increase of $\mathrm{EI}\left(\mathrm{NO}_{x}\right)$ from 0.1 to $100 \mathrm{~g}\left(\mathrm{NO}_{2}\right.$-equivalents) $/\left(\mathrm{kg}\right.$ fuel) (baseline value: $\mathrm{EI}\left(\mathrm{NO}_{x}\right)=26.8 \mathrm{~g} / \mathrm{kg}$ ) leads to a decrease of $\varepsilon$ from $9.66 \%$ to $2.87 \%$. This is a result of the reactions of $\mathrm{OH}$ with $\mathrm{NO}_{x}$ competing with the $\mathrm{SO}_{2}+\mathrm{OH}$ reaction. Figure 9 shows the sulfur conversion efficiency $\varepsilon$ as a function of the initial ratio $\mathrm{NO}_{2} / \mathrm{NO}_{x}: \varepsilon$ decreases from $5.13 \%$ to $2.37 \%$ when $\left(\mathrm{NO}_{2} / \mathrm{NO}_{x}\right)_{0}$ increases from $0 \%$ (i.e., all $\mathrm{NO}_{x}$ composed of $\mathrm{NO}$ ) to $50 \%$ (i.e., $\mathrm{NO}_{x}$ composed of $\mathrm{NO}$ and $\mathrm{NO}_{2}$ at equal mole fractions) (baseline value: $15.9 \%$ ), because the rate constant for $\mathrm{NO}_{2}+\mathrm{OH}$ is greater than that for $\mathrm{NO}+\mathrm{OH}$.

Finally, figure 10 shows that the sulfur conversion efficiency $\varepsilon$ behind the combustor is additive to the 


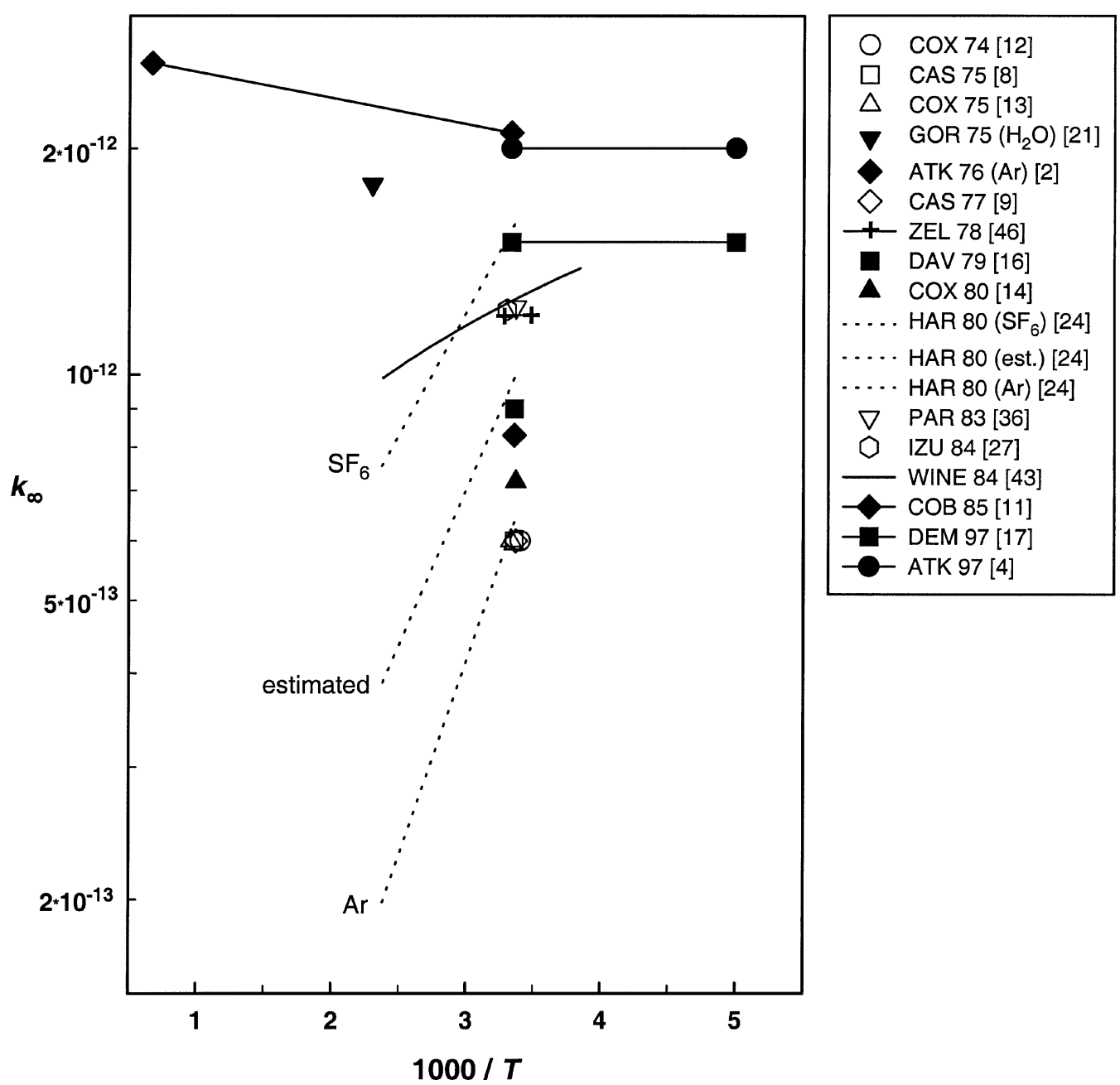

Figure 4. Arrhenius graph of the published data on the high pressure rate constant $k_{\infty}$ for the reaction $\mathrm{SO}_{2}+\mathrm{OH}+\mathrm{M} \rightarrow \mathrm{HSO}+\mathrm{M}$, extracted from the NIST data base [34]. Temperature $T$ is given in $\mathrm{K}$, and $k_{\infty}$ in $\mathrm{cm}^{3}$ molecule $\mathrm{s}^{-1}$. Acronyms in the legend refer to the corresponding references. Bath gases $\mathrm{M}$ other than $\mathrm{N}_{2}$ are indicated.

conversion efficiency $\varepsilon_{0}$ already established within the combustor. For our baseline case we assumed $\varepsilon_{0}=0$ (see section 2), so that the conversion efficiency behind the combustor equals the overall efficiency. But if there is already a certain percentage $\varepsilon_{0}$ of sulfur converted (mostly into $\mathrm{SO}_{3}$ ) in the combustor, the efficiencies simply may be added.

\section{Discussion}

The range of our simulated fuel sulfur conversion efficiency $\varepsilon$ behind the combustor of typically a few percent agrees very well with other modelling studies considering the oxidation within the aircraft engine ([7,26, $33]$ ). For some sets of model parameters and if there is already a certain percentage $\varepsilon_{0}$ of sulfur converted within the combustor, the efficiency may even exceed $10 \%$. Simulations for the same scenario behind a JT9D-7A engine by Tremmel et al. [40] yielded lower conversion efficiencies $(\varepsilon \approx 0.5 \%)$. This is mainly a result of different reaction mechanisms and different reaction rate constants (especially for reaction $\mathrm{SO}_{2}+\mathrm{OH}$ ) used in these studies. The rate constants used here are much better applicable for the intra-engine high-temperature regime between the combustor exit and the nozzle exit.

The range of our simulated $\varepsilon$ also agrees very well with several experimental studies, where sulfuric acid has been measured directly (e.g., [20,1,15]). On the other hand, our results cannot explain the much higher sulfur conversion values, which have been estimated from in-flight measurements of volatile particles behind a Concorde aircraft $(\varepsilon>12-45 \%$ [18]), and behind a B757 (6\% and $31 \%$ [35]). A possible reason for these 


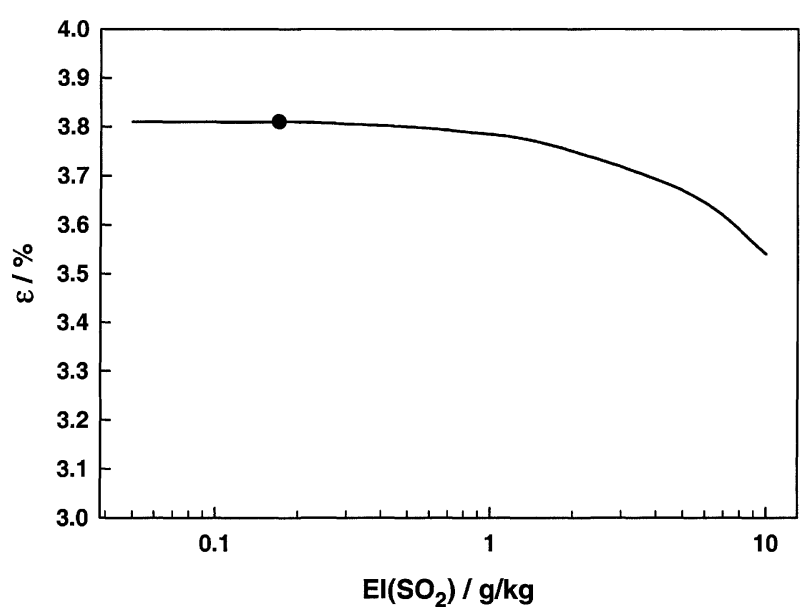

Figure 5. Dependence of the sulfur conversion efficiency $\varepsilon$ on the $\mathrm{SO}_{2}$ emission index $\mathrm{EI}\left(\mathrm{SO}_{2}\right)$. The symbol indicates the baseline case.

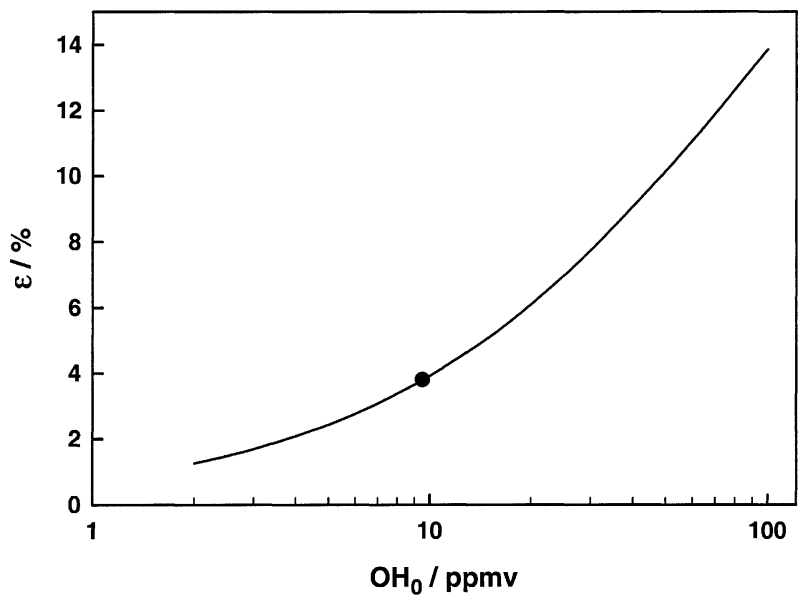

Figure 6. Dependence of the sulfur conversion efficiency $\varepsilon$ on the initial $\mathrm{OH}$ mixing ratio $\mathrm{OH}_{0}$. The symbol indicates the baseline case.

large values may be due to the assumption that the volatile particles are composed only of $\mathrm{H}_{2} \mathrm{SO}_{4}$ and $\mathrm{H}_{2} \mathrm{O}$. However, recent studies show that part of the volatile material may be species other than $\mathrm{H}_{2} \mathrm{SO}_{4}[30,38]$, e.g. organic species [45]. Furthermore, the values estimated by Fahey et al. [18] are based only on 2 plume encounters with $\mathrm{CN}$ (condensation nuclei) and $\mathrm{CO}_{2}$ measurements. Because of the unknown size distribution, the size of the measured aerosol was set according to the cut-off limit of the $\mathrm{CN}$ counters, and any uncertainty in the assumed size distribution and the cut-off size causes large uncertainties in the conversion rates. The $\mathrm{H}_{2} \mathrm{SO}_{4}$ fraction estimated by Miake-Lye et al. [35] is deduced as a remainder from measured $\mathrm{CO}_{2}$ and $\mathrm{SO}_{2}$ data with large statistical uncertainties $(0-34 \%$ and $16-52 \%)$. Their results also depend on the accuracy of the determined fuel sulfur content, the error of which was not discussed in [35]. Our

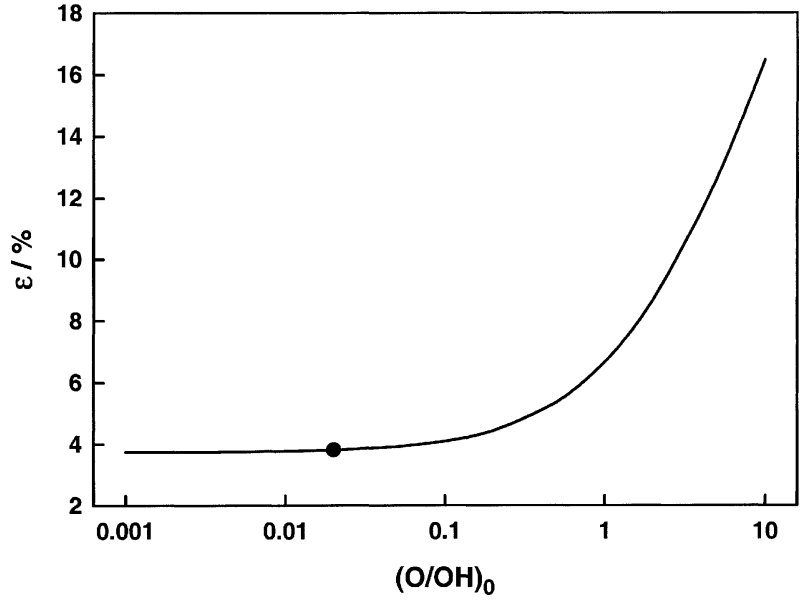

Figure 7. Dependence of the sulfur conversion efficiency $\varepsilon$ on the initial $\mathrm{O} / \mathrm{OH}$ ratio $(\mathrm{O} / \mathrm{OH})_{0}$. The symbol indicates the baseline case.

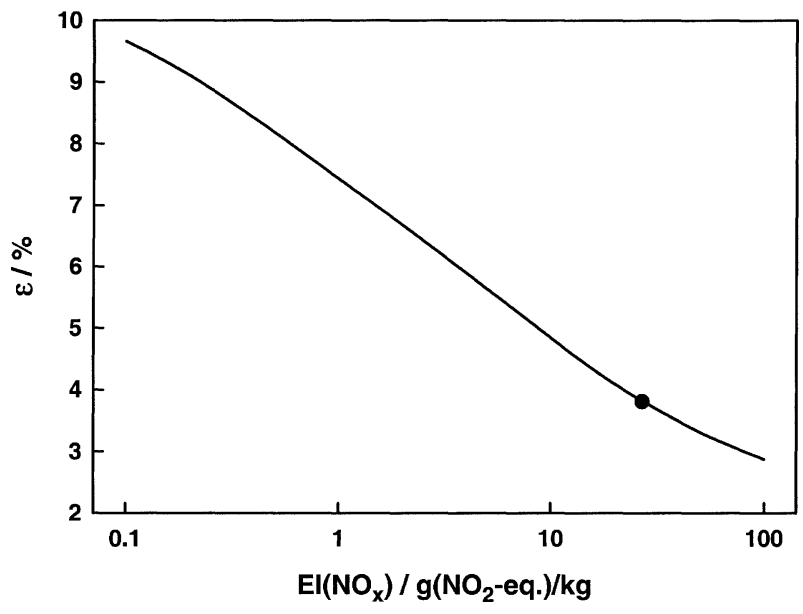

Figure 8. Dependence of the sulfur conversion efficiency $\varepsilon$ on the $\mathrm{NO}_{x}$ emission index $\mathrm{EI}\left(\mathrm{NO}_{x}\right)$. The symbol indicates the baseline case.

own experience shows that the repeatability of fuel sulfur analysis may imply errors around 10\% [39].

We have shown, that the uncertainty of $k\left(\mathrm{SO}_{2}+\mathrm{OH}\right)$ results in an uncertainty range of $1.1 \%<\varepsilon<6.2 \%$ for our simulation scenario. The effect of the reaction $\mathrm{SO}_{2}+$ $\mathrm{O}+\mathrm{M} \rightarrow \mathrm{SO}_{3}+\mathrm{M}$ on $\varepsilon$ is very small if the initial mixing ratio of $\mathrm{O}$ is assumed to be smaller than that of $\mathrm{OH}$. An equilibrium calculation with our model for conditions at the combustor exit yields an estimated $\mathrm{O} / \mathrm{OH}$ ratio of about $2 \%$, which agrees very well with that used by Lukachko et al. [33]. Our equilibrium calculations and those performed by Chameides [10] indicate that $\mathrm{O}$ should exceed $\mathrm{OH}$ not below $2500 \mathrm{~K}$.

The variation of the initial $\mathrm{SO}_{2}$ mixing ratio (i.e., $\mathrm{EI}\left(\mathrm{SO}_{2}\right)$ or fuel sulfur content) yields a slight decrease of $\varepsilon$ with increasing $\mathrm{EI}\left(\mathrm{SO}_{2}\right)$, for $\mathrm{EI}\left(\mathrm{SO}_{2}\right)$ exceeding 


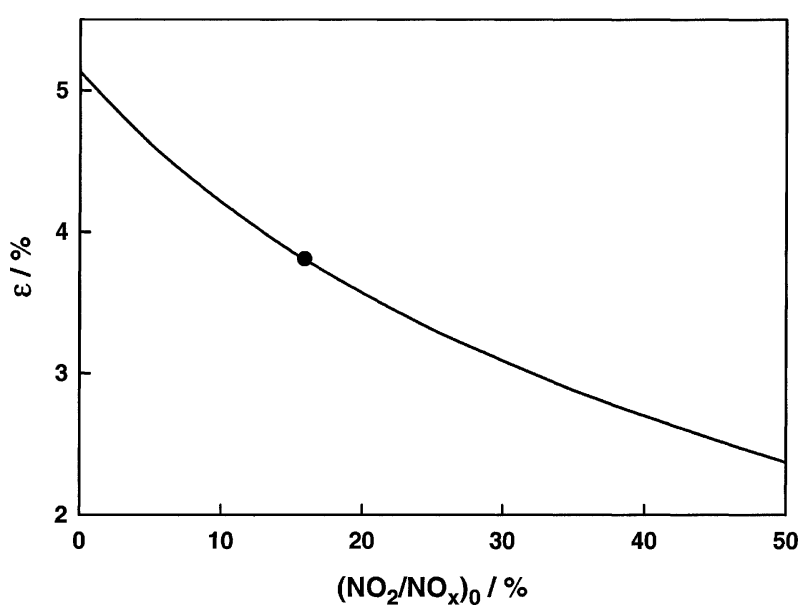

Figure 9. Dependence of the sulfur conversion efficiency $\varepsilon$ on the initial $\mathrm{NO}_{2} / \mathrm{NO}_{x}$ ratio $\left(\mathrm{NO}_{2} / \mathrm{NO}_{x}\right)_{0}$. The symbol indicates the baseline case.

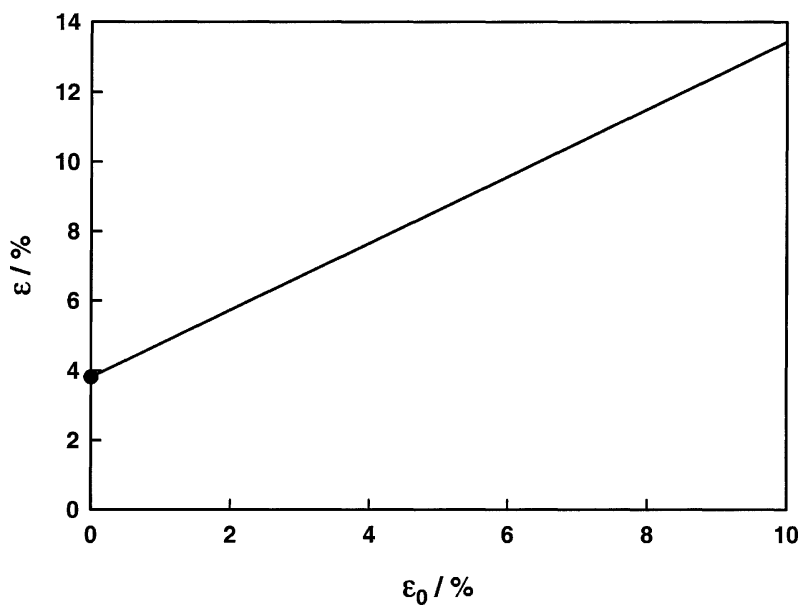

Figure 10. Dependence of the sulfur conversion efficiency $\varepsilon$ on the initial sulfur conversion efficiency $\varepsilon_{0}$. The symbol indicates the baseline case.

$1 \mathrm{~g} / \mathrm{kg}$. Other studies indicate that the dependence of $\varepsilon$ on the fuel sulfur content is still unsettled, and it is even unknown whether $\varepsilon$ decreases (this study, and [7]) or increases [35] with increasing fuel sulfur content. The dependencies of $\varepsilon$ on $\mathrm{OH}_{0}, \mathrm{O}_{0}$, and $\mathrm{EI}\left(\mathrm{NO}_{x}\right)$ qualitatively agree with those found by Kärcher et al. [28].

\section{Summary and conclusions}

We have simulated the fuel sulfur conversion efficiency $\varepsilon$ behind the combustor of a JT9D-7A aircraft engine in flight using an extended exhaust plume chemistry model, yielding $\varepsilon=3.8 \%$ for a baseline scenario. The simulations show that the sulfur conversion efficiency is crucially dependent on model assumptions like reaction rate constants and initial mixing ratios at the combustor exit. The effect of the uncertainties and variabilities of these parameters on $\varepsilon$ has been demonstrated in several sensitivity studies.

Concerning the rate constants, the uncertainty of the reaction rate constant $k$ for $\mathrm{SO}_{2}+\mathrm{OH}+\mathrm{M} \rightarrow \mathrm{HSO}_{3}+\mathrm{M}$ has the greatest effect on $\varepsilon$; the uncertainty of $k\left(\mathrm{SO}_{2}+\right.$ $\mathrm{OH})$ results in an uncertainty range of $1.1 \%<\varepsilon<6.2 \%$ for our simulation scenario. The effect of the reaction $\mathrm{SO}_{2}+\mathrm{O}+\mathrm{M} \rightarrow \mathrm{SO}_{3}+\mathrm{M}$ on $\varepsilon$ is very small if the initial mixing ratio of $\mathrm{O}$ is smaller than that of $\mathrm{OH}$. The sensitivity tests show that the effect of the reaction $\mathrm{SO}_{2}+$ $\mathrm{O}$ on $\varepsilon$ becomes increasingly important for an $\mathrm{O} / \mathrm{OH}$ ratio exceeding about $10 \%$. The conversion efficiency is insensitive to the subsequent $\mathrm{SO}_{x}$ reactions $\mathrm{HSO}_{3}+$ $\mathrm{O}_{2} \rightarrow \mathrm{SO}_{3}+\mathrm{HO}_{2}$ and $\mathrm{SO}_{3}+\mathrm{H}_{2} \mathrm{O}+\mathrm{M} \rightarrow \mathrm{H}_{2} \mathrm{SO}_{4}+$ $\mathrm{M}$. The uncertainties of the rate constants of the most important $\mathrm{HO}_{x}$ and $\mathrm{NO}_{x}$ reactions lead to variations of $\varepsilon$ between $3.5 \%$ and $4.1 \%$.

The variation of the initial $\mathrm{SO}_{2}$ mixing ratio (i.e., $\mathrm{EI}\left(\mathrm{SO}_{2}\right)$ or fuel sulfur content) yields a slight decrease of $\varepsilon$ with increasing $\mathrm{EI}\left(\mathrm{SO}_{2}\right)$, for $\mathrm{EI}\left(\mathrm{SO}_{2}\right)$ exceeding $1 \mathrm{~g} / \mathrm{kg}$. The initial mixing ratio of $\mathrm{OH}$ has a strong but less than linear effect on $\varepsilon$; an increase from 2 up to $100 \mathrm{ppmv}$ results in an increase of $\varepsilon$ from $1.3 \%$ up to $13.9 \%$. For our simulation scenario, the uncertainty range of $5.7 \mathrm{ppmv}$ $<\mathrm{OH}_{0}<14.7$ ppmv leads to an uncertainty range of $2.7 \%<\varepsilon<5.0 \%$. If the initial mixing ratio of $\mathrm{O}$ exceeds that of $\mathrm{OH}$, its influence would also become very large. Increasing emission indices of $\mathrm{NO}_{x}$ and increasing initial $\mathrm{NO}_{2} / \mathrm{NO}_{x}$ ratios lead to decreasing sulfur conversion efficiencies because of competition of the $\mathrm{NO}_{x}+\mathrm{OH}$ reactions with the $\mathrm{SO}_{2}+\mathrm{OH}$ reaction. We have also shown that the sulfur conversion efficiency $\varepsilon$ behind the combustor is additive to the conversion efficiency $\varepsilon_{0}$ already established within the combustor.

As a conclusion, it is absolutely necessary for modelling studies simulating the fuel sulfur conversion efficiency to specify the rate constant $k\left(\mathrm{SO}_{2}+\mathrm{OH}\right)$ and all other important parameters used as model assumptions. This provides the possibility to compare between model results of different studies. Furthermore, we conclude that there is a need of laboratory measurements of $k\left(\mathrm{SO}_{2}+\mathrm{OH}\right)$ for a temperature range above $400 \mathrm{~K}$ up to about $2000 \mathrm{~K}$.

In future studies we will investigate the effects of engine parameters like temperature, pressure, cooling air flow, and time scales between combustor and nozzle exit on the conversion efficiency.

\section{Acknowledgements}

We would like to thank G. Gleitsmann and R. Zellner, University Essen, and B. Kärcher, DLR Oberpfaffenhofen, for discussions and comments on the manuscript. This research is supported by the Commission of the European Union within the CHEMICON project. 


\section{References}

[1] Arnold F., Stilp T., Busen R., Schumann U., Jet engine exhaust chemiion measurements: Implications for gaseous $\mathrm{SO}_{3}$ and $\mathrm{H}_{2} \mathrm{SO}_{4}$, Atmos. Environ. 32 (1998) 3073-3077.

[2] Atkinson R., Perry R.A., Pitts J.N. Jr., Rate constants for the reactions of the $\mathrm{OH}$ radical with $\mathrm{NO}_{2}(\mathrm{M}=\mathrm{Ar}$ and $\left.\mathrm{N}_{2}\right)$ and $\mathrm{SO}_{2}(\mathrm{M}=\mathrm{Ar})$, J. Chem. Phys. 65 (1976) 306.

[3] Atkinson R., Baulch D.L., Cox R.A., Hampson R.F. Jr., Kerr J.A., Troe J., Evaluated kinetic and photochemical data for atmospheric chemistry: Supplement III, J. Phys. Chem. Ref. Data 18 (1989) 881-1095.

[4] Atkinson R., Baulch D.L., Cox R.A., Hampson R.F. Jr., Kerr J.A., Rossi M.J., Troe J., Evaluated kinetic, photochemical and heterogeneous data for atmospheric chemistry: Supplement V, J. Phys. Chem. Ref. Data 26 (1997) 521-1011.

[5] Baulch D.L., Cobos C.J., Cox R.A., Esser C., Frank P., Just T., Kerr J.A., Pilling M.J., Troe J., Walker R.W., Warnatz J., Evaluated kinetic data for combustion modelling, J. Phys. Chem. Ref. Data 21 (1992) 411-429.

[6] Brown R.C., Miake-Lye R.C., Anderson M.R., Kolb C.E., Resch T.J., Aerosol dynamics in near-field aircraft plumes, J. Geophys. Res. 101 (1996) 22939-22953.

[7] Brown R.C., Anderson M.R., Miake-Lye R.C., Kolb C.E., Sorokin A.A., Buriko Y.Y., Aircraft exhaust sulfur emissions, Geophys. Res. Lett. 23 (1996) 3603-3606.

[8] Castleman A.W. Jr., Davis R.E., Munkelwitz H.R., Tang I.N., Wood W.P., Kinetics of association reactions pertaining to $\mathrm{H}_{2} \mathrm{SO}_{4}$ aerosol formation, Int. J. Chem. Kinet. 7 (1975) 629.

[9] Castleman A.W. Jr., Tang I.N., Kinetics of the association reaction of $\mathrm{SO}_{2}$ with the hydroxyl radical, J. Photochem. 6 (1977) 349.

[10] Chameides, W.L., The role of lightning in the chemistry of the atmosphere, in: The Earth's Electrical Environment, National Academy Press, Washington, D.C., 1986, p. 70 .

[11] Cobos C.J., Troe J., Theory of thermal unimolecular reactions at high pressures. II. Analysis of experimental results, J. Chem. Phys. 83 (1985) 1010-1015.

[12] Cox R.A., The photolysis of nitrous acid in the presence of carbon monoxide and sulphur dioxide, J. Photochem. 3 (1974) 291.

[13] Cox R.A., The photolysis of gaseous nitrous acid A technique for obtaining kinetic data on atmospheric photooxidation reactions, Int. J. Chem. Kinet. 7 (1975) 379.

[14] Cox R.A., Sheppard, D., Reactions of OH radicals with gaseous sulphur compounds, Nature 284 (1980) 330.

[15] Curtius J., Sierau B., Arnold F., Baumann R., Busen R., Schulte P., Schumann U., First direct sulfuric acid detection in the exhaust plume of a jet aircraft in flight, Geophys. Res. Lett. 25 (1998) 923-926.

[16] Davis D.D., Ravishankara A.R., Fischer S., $\mathrm{SO}_{2}$ oxidation via the hydroxyl radical: atmospheric fate of $\mathrm{HSO}_{x}$ radicals, Geophys. Res. Lett. 6 (1979) 113.

[17] DeMore W.B., Sander S.P., Golden D.M., Hampson R.F., Kurylo M.J., Howard C.J., Ravishankara A.R., Kolb C.E., Molina M.J., Chemical kinetics and photochemical data for use in stratospheric modeling, Evaluation number 12, JPL Publication 97-4, 1997.

[18] Fahey D.W., Keim E.R., Boering K.A., Brock C.A., Wilson J.C., Jonsson H.H., Anthony S., Hanisco T.F., Wennberg P.O., Miake-Lye R.C., Salawitch R.J., Louisnard N., Woodbridge E.L., Gao R.S., Donnelly S.G., Wamsley R.C., Del Negro L.A., Solomon S., Daube B.C., Wofsy S.C., Webster C.R., May R.D., Kelly K.K., Loewenstein M., Podolske J.R., Chan K.R., Emission measurements of the Concorde supersonic aircraft in the lower stratosphere, Science 270 (1995) 70-74.

[19] Fahey D.W., Schumann U., Ackerman S., Artaxo P., Boucher O., Danilin M.Y., Kärcher B., Minnis P., Nakajima T., Toon O.B., Aviation-produced aerosols and cloudiness, in: IPCC (Intergovernmental Panel on Climate Change) Special Report on Aviation and the Global Atmosphere (Chapter 3), Cambridge University Press, Cambridge, in press, 1999.

[20] Frenzel A., Arnold F., Sulfuric acid cluster ion formation by jet engines: Implications for sulfuric acid formation and nucleation, in: Schumann U., Wurzel D. (Eds.), Impact of Emissions from Aircraft and Spacecraft Upon the Atmosphere, Proc. Intern. Sci. Colloquium, Köln, April 18-20, 1994, Deutsche Forschungsanstalt für Luftund Raumfahrt, Oberpfaffenhofen, Germany, 1994, pp. 106-112.

[21] Gordon S., Mulac W.A., Reaction of the $\mathrm{OH}\left(\mathrm{X}_{2} \mathrm{O}\right)$ radical produced by the pulse radiolysis of water vapor, Int. J. Chem. Kinet. 7 (1975) 289.

[22] Hanisco T.F., Wennberg P.O., Cohen R.C., Anderson J.G., Fahey D.W., Keim E.R., Gao R.S., Wamsley R.C., Donnelly S.G., Del Negro L.A., Salawitch R.J., Kelly K.K., Proffit M.H., The role of $\mathrm{HO}_{x}$ in super- and subsonic aircraft exhaust plumes, Geophys. Res. Lett. 24 (1997) 65-68.

[23] Harris G.W., Wayne R.P., Reaction of hydroxyl radicals with $\mathrm{NO}, \mathrm{NO}_{2}$ and $\mathrm{SO}_{2}$, J. Chem. Soc. Faraday Trans. I 71 (1975) 610.

[24] Harris G.W., Atkinson R., Pitts J.N. Jr., Temperature dependence of the reaction $\mathrm{OH}+\mathrm{SO}_{2}+\mathrm{M}=\mathrm{HSO}_{3}+$ $\mathrm{M}$ for $\mathrm{M}=\mathrm{Ar}$ and $\mathrm{SF}_{6}$, Chem. Phys. Lett. 69 (1980) 378.

[25] Harris B.W., Conversion of sulfur dioxide to sulfur trioxide in gas turbine exhaust, J. Eng. Gas Turbines Power 112 (1990) 585-589.

[26] Hunter S.C., Formation of $\mathrm{SO}_{3}$ in gas turbines, T. ASME J. Eng. Power 104 (1982) 44-51.

[27] Izumi K., Mizuochi M., Yoshloka M., Murano K., Fukuyama T., Redetermination of the rate constant for the reaction of $\mathrm{OH}$ radicals with $\mathrm{SO}_{2}$, Environ. Sci. Technol. 18 (1984) 116.

[28] Kärcher B., Hirschberg M.M., Fabian P., Small-scale chemical evolution of aircraft exhaust species at cruising altitudes, J. Geophys. Res. 101 (1996) 15169-15190.

[29] Kärcher B., Fahey D.W., The role of sulfur emission in volatile particle formation in jet aircraft exhaust plumes, Geophys. Res. Lett. 24 (1997) 389-392.

[30] Kärcher B., Yu F., Schröder F.P., Turco R.P., Ultrafine aerosol particles in aircraft plumes: Analysis of growth mechanisms, Geophys. Res. Lett. 25 (1998) 2793-2796. 
[31] Lee Y.-Y., Kao W.-C., Lee Y.-P., Kinetics of the reaction $\mathrm{OH}+\mathrm{SO}_{2}$ in $\mathrm{He}, \mathrm{N}_{2}$, and $\mathrm{O}_{2}$ at low pressure, J. Phys. Chem. 94 (1990) 4535.

[32] Leu M.T., Rate constants for the reaction of $\mathrm{OH}$ with $\mathrm{SO}_{2}$ at low pressure, J. Phys. Chem. 86 (1982) 4558.

[33] Lukachko S.P., Waitz I.A., Miake-Lye R.C., Brown R.C., Anderson M.R., Production of sulfate aerosol precursors in the turbine and exhaust nozzle of an aircraft engine, J. Geophys. Res. 103 (1998) 16159-16174.

[34] Mallard W.G., Westley F., Herron J.T., Hampson R.F., Frizzell D.H., NIST Chemical Kinetics Database, National Institute of Standards and Technology, Gaithersburg, MD, USA, 1998.

[35] Miake-Lye R.C., Anderson B.E., Cofer W.R., Wallio H.A., Nowicki G.D., Ballenthin J.O., Hunton D.E., Knighton W.B., Miller T.M., Seeley J.V., Viggiano A.A., $\mathrm{SO}_{x}$ oxidation and volatile aerosol in aircraft exhaust plumes depend on fuel sulfur content, Geophys. Res. Lett. 25 (1998) 1677-1680.

[36] Paraskevopoulos G., Singleton D.L., Irwin R.S., Rates of $\mathrm{OH}$ radical reactions. The reaction $\mathrm{OH}+\mathrm{SO}_{2}+\mathrm{N}_{2}$, Chem. Phys. Lett. 100 (1983) 83.

[37] Patrick R., Golden D.M., Third-order rate constants of atmospheric importance, Int. J. Chem. Kinet. 15 (1983) 1189.

[38] Schröder F.P., Kärcher B., Petzold A., Baumann R., Busen R., Hoell C., Schumann U., Ultrafine aerosol particles in aircraft plumes: In situ observations, Geophys. Res. Lett. 25 (1998) 2789-2792.

[39] Schumann U., Ström J., Busen R., Baumann R., Gierens K., Krautstrunk M., Schröder F.P., Stingl J., In situ observations of particles in jet aircraft exhausts and contrails for different sulfur-containing fuels, J. Geophys. Res. 101 (1996) 6853-6869.

[40] Tremmel H.G., Schlager H., Konopka P., Schulte P., Arnold F., Klemm M., Droste-Franke B., Observations and model calculations of jet aircraft exhaust products at cruise altitude and inferred initial $\mathrm{OH}$ emissions, J. Geophys. Res. 103 (1998) 10803-10816.

[41] Tsang W., Hampson R.F., Chemical kinetic data base for combustion chemistry. Part I. Methane and related compounds, J. Phys. Chem. Ref. Data 15 (1986) 10871279.

[42] Tsang W., Herron J.T., Chemical kinetic data base for propellant combustion. I. Reactions involving $\mathrm{NO}, \mathrm{NO}_{2}$, $\mathrm{HNO}, \mathrm{HNO}_{2}, \mathrm{HCN}$, and $\mathrm{N}_{2} \mathrm{O}$, J. Phys. Chem. Ref. Data 20 (1991) 609-663.

[43] Wine P.H., Thompson R.J., Ravishankara A.R., Semmes D.H., Gump C.A., Torabi A., Nicovich J.M., Kinetics of the reaction $\mathrm{OH}+\mathrm{SO}_{2}+\mathrm{M}=\mathrm{HOSO}_{2}+\mathrm{M}$. Temperature and pressure dependence in the falloff region, J. Phys. Chem. 88 (1984) 2095

[44] Yu F., Turco R.P., The role of ions in the formation and evolution of particles in aircraft plumes, Geophys. Res. Lett. 24 (1997) 1927-1930.

[45] Yu F., Turco R.P., Kärcher B., The possible role of organics in the formation and evolution of ultrafine aircraft particles, J. Geophys. Res. 104 (1999) 4079-4087.

[46] Zellner R., Recombination reactions in atmospheric chemistry, Ber. Bunsenges. Phys. Chem. 82 (1978) 1172. 